\title{
Economic Governance and Economic Growth in South and East Asia \& Pacific Region: Evidence from Systematic Literature Reviews and Meta-analysis
}

\author{
Sridevi Yerrabati ${ }^{1, *}$, Denise Hawkes ${ }^{2}$ \\ ${ }^{1}$ Business School, University of Greenwich, Old Royal Naval College, London, UK \\ ${ }^{2}$ UCL Institute of Education, University of London, London, UK
}

Copyright (C) 2015 Horizon Research Publishing All rights reserved.

\begin{abstract}
With economists and policy makers recognising the role of governance for growth, recent research focus is on governance and its impact on growth. However, with ever growing number of studies using different methodologies, data sources and country groupings, a high amount of heterogeneity is created among reported results. This has left both policy makers and researchers having different views on the importance of governance for growth. This paper has meta-synthesised the empirical evidence on governance and growth in South and East Asia Pacific countries based on 29 studies with 554 estimates from 1980 - 2012. The empirical results show that while corruption is significantly and negatively correlated with growth, government effectiveness and regulation are positively and significantly correlated. Political stability and law have no important effect on economic growth. We conclude that empirical research literature on governance and growth has failed to provide evidence of a true effect of voice and accountability on growth. Finally, overall governance is important for growth. Our results have important policy implications.
\end{abstract}

Keywords Governance, Economic Growth, Meta-regression Analysis, Systematic Literature Review, South and East Asia \& Pacific Counties

JEL codes: B5, O4, 05

\section{Introduction}

Research on economic growth (hereafter referred to as growth) in general and particularly in the case of South and East Asia \& Pacific counties has exploded in the last few years (Zhang, [51]). The economic growth literature is filled with empirical studies that have looked at the elusive and ever important question of what causes economic growth (Anwar and Cooray, [4]; Haggard and Tiede, [31]). The focus of most of the empirical studies in this field has been on conventional sources of economic growth such as domestic investment, education, foreign investment and others. With economists and policy makers recognising the role of economic governance (hereafter referred to as governance) for growth, recent research focus is on governance and its impact on growth. However, with ever growing number of studies using different methodologies, data sources and country groupings, a high amount of heterogeneity is created among reported results. This has left both policy makers and researchers having different views on the importance of governance for growth.

North in his institutional theory posits that institutions in the form of political, economic and structural interactions are human-made constraints which aim to decrease the level of uncertainty and allow for firms and individuals to interact efficiently. While governance aims to facilitate investments and speed up economic activity, it can effect transaction (ex: cost of protecting property rights) and transformation costs (ex: by effecting production interruptions) which in turn can slow down the economic activity.

The relationship between governance and growth has been a highly debated topic in the Asian context. While some authors argue that governance shows positive effects on growth, others are of the view that it is not the case. Governance establishes the framework for economic activity within a country. Good governance on one hand can create an environment that promotes economic activity, provides incentives to invest and economic growth. Bad governance on the other hand can have detrimental effects on economic growth by increasing transaction costs and by causing delays in the investment process (Kaufmann et al, [35], Gani, [27]). This study is motivated by increased effort from both policy makers and researchers towards understanding the overall impact of governance on economic growth and improving the governance quality in general.

The aim of this study therefore is to contribute to evidence based policy making and to academic research on the 
governance growth relationship by providing meta-synthesis of empirical evidence on various measures of governance and growth. This study also identifies factors causing heterogeneity in results, pointing to policy implications of our results and identifying potential avenues for future research. In order to address the aims of this study, the following questions are raised in this study: Firstly, is there any genuine effect of governance on economic growth? Why do governance growth studies report such divergent results? Is the heterogeneity due to the data generating process or is it due to differences in research design?

The definition of economic governance has evolved over the last few years. According to Kaufmann et al, [35] Governance consists of the traditions and institutions by which authority in a country is exercised. This includes the process by which governments are selected, monitored and replaced; the capacity of the government to effectively formulate and implement sound policies; and the respect of citizens and the state for the institutions that govern economic and social interactions among them. Good, transparent and efficient governance in host countries ensures the safety of investments and thus attracts foreigners to invest. While there are many international and local authorities which give both subjective and objective information on governance, literature in the field of governance and inward FDI has used four main sources. They are worldwide governance indicators provided by Kaufmann et al., [36] under World Bank project, Freedom House measure of voice and accountability and political rights, Polity dataset and International Country Risk Guide (ICRG).

These different datasets on the quality of governance raise the issue of divergence in various measures of governance measured by these institutions. In order to synthesise governance - growth effects, we delved deeper into the sub measures of each measure of governance to synthesise them based on the common sub measures. After observing the individual variables (representative sources) that have been used in measuring governance by these different data sources, we have classified governance into 7 measures based on World Wide governance measures. These seven measures are termed hereafter as voice and accountability, political stability, government effectiveness, regulation, law, corruption and aggregate governance.

After the above introduction, the rest of the paper is organised as follows. Section 2 outlines the methodology used in this study followed by systematic review of literature in section 3. Section 4 presents, analysis and discusses the results, with section 5 concluding the study by outlining the limitations, together with some policy and research implications.

\section{Methodology}

The review methodology used in this thesis i.e the methods used for searching studies, study selection, critical evaluation and data extraction is informed by three sources. Firstly, Cambell and Cochrane Collaboration guidelines on systematic reviews in healthcare and social policy; secondly, Centre for Reviews and Dissemination (CRD, [11]) of the University of York; thirdly, Evidence for Policy and Practice Information and Co-ordinating Centre (EPPI-Centre) of the Institute of Education. Data analysis is informed by Doucouliagos et al., [14], Doucouliagos and Ulubasoglu [17] and Stanley and Doucouliagos [48]. Reporting guidelines are informed by Stanley et al., [49].

For published studies, databases such as EBSCO host (Business and economics database), web of knowledge (social sciences), International Bibliography of the social sciences (Economics, politics, sociology, anthropology and Economics), Science direct (science and humanities), Swetswise and JSTOR (social sciences) were used. For unpublished studies, databases such as World Bank e-library, Harvard Kennedy e-library, Asian Development Bank e-library, National Bureau of economic research and IMF e-library were used. In addition to these databases, two search engines namely Google scholar and Web of Knowledge. In addition to the above, manual search was performed in order to identify grey literature using two approaches - snowball approach and random search of studies in 5 journals. Under the snowball approach we have started with the reference list of studies identified through systematic review and proceeded to find new studies. These exhaustive searches were carried out to identify all possible studies on measures of governance and inward FDI.

The key words that were used to search 'title', 'abstract', 'text', and 'keyword' in databases listed above are listed in the appendix (appendix 1). The time period of the search was January 1980 - December 2012. With regards to the language of publication, studies published in English language only were used.

Searching databases for both published and unpublished studies, 5414 were retrieved. From these, 875 and 168 records were deleted through automatic and manual duplicate search respectively. This resulted in 4371 unique records that either analysed or estimated the relationship between economic governance and economic growth. First stage screening of these unique studies was done by reading title and abstract of each study which reduced the number of studies to 91 (figure 1). The relevance of each study was interrogated with two questions: Firstly, does the study estimate the relationship between economic governance and economic growth? Secondly, does the study analyse the relationship between economic governance and economic growth? Only studies which have estimated the relationship were considered for critical evaluation stage. 


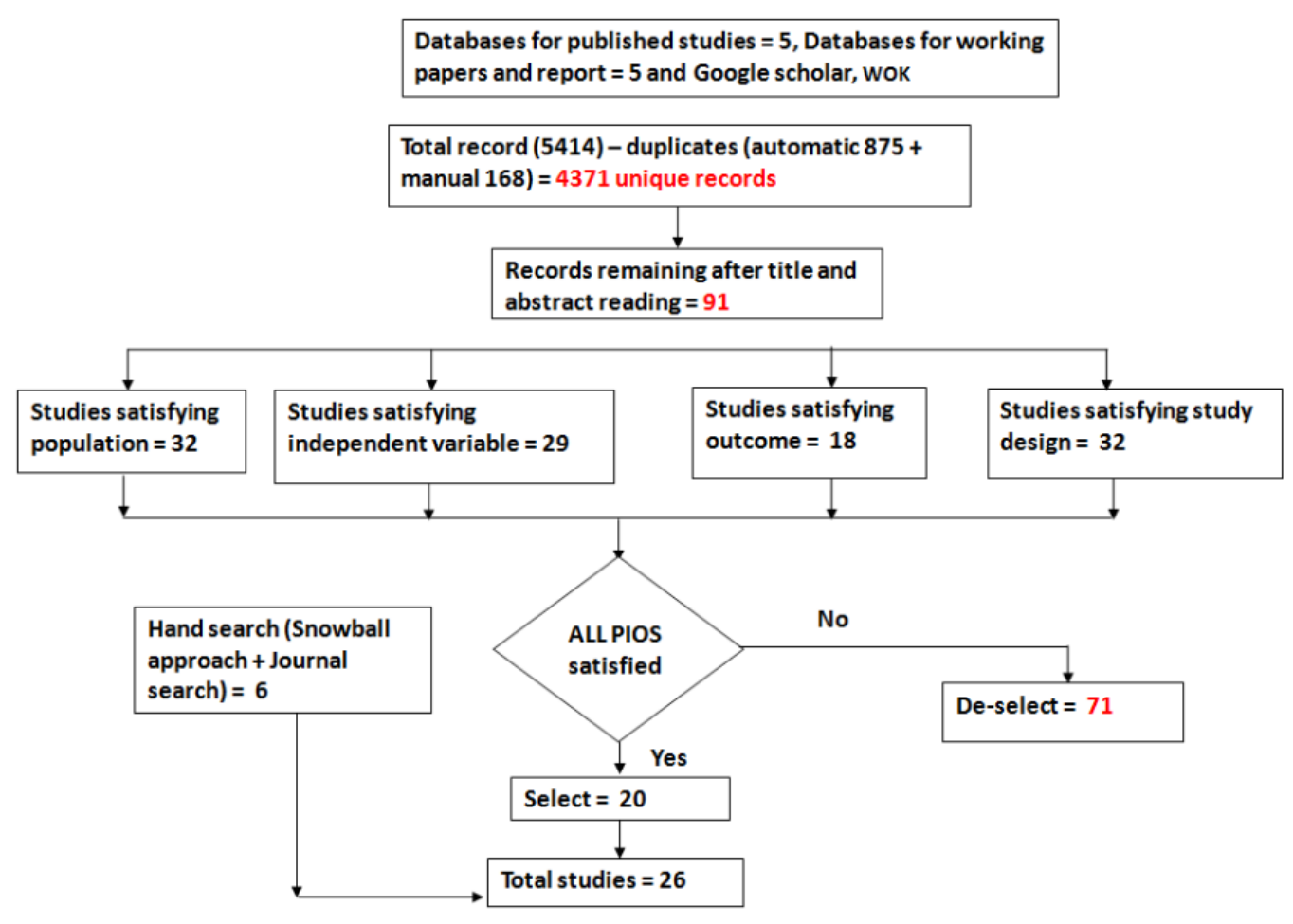

Figure 1. Summary of methodology used in the study

Critical evaluation of each of 91 studies was performed using PIOS criteria (Population, Independent variable, Outcome variable and Study design) (appendix 2). 32 studies have satisfied population criteria (studies including at least one of South and East Asia and Pacific countries), 29 studies have satisfied independent variable (i.e. economic governance), 18 studies have found to satisfy outcome variable (i.e. economic growth) and 32 studies satisfied study design. In total, 20 studies were found to satisfy all four criteria (appendices 3). Another 6 studies were added through hand search leaving a total of 26 studies for meta-regression analysis.

The general form of econometric models used in the above 26 studies with linear terms only (equation 1) and those with linear, non-linear and interaction terms (equation 2) appeared as follows.

$$
\mathrm{Y}_{\mathrm{it}}=\alpha_{0}+\alpha_{1} \mathrm{~F}_{\mathrm{it}}+\gamma \mathrm{X}_{\mathrm{it}}+\varepsilon_{\mathrm{it}}
$$

$\mathrm{Y}_{\text {it }}=\alpha_{0}+\alpha_{1} \mathrm{~F}_{\mathrm{it}}+\alpha_{2} \mathrm{~F}_{\mathrm{it}} \mathrm{K}_{\mathrm{it}}+\alpha_{3} \mathrm{~F}_{\text {it }}^{2}+\gamma \mathrm{X}_{\mathrm{it}}+\varepsilon_{\mathrm{it}}$ equation

In equations 1 and $2, \mathrm{Y}_{\mathrm{it}}$ stands for dependent variable (economic growth); $\alpha_{0}$ is the constant term and $\alpha 1$ measures the marginal effect of $\mathrm{F}$ on $\mathrm{Y}$; $\mathrm{F}$ stands for variable of interest i.e. various measures of governance; therefore, $F_{\text {it }}$ measures the linear effect of measures of governance on economic growth; $F_{i t} \cdot K_{i t}$ is the interaction term which measures the effect of $\mathrm{F}$ on economic growth conditional on the value of $\mathrm{K}$; $\mathrm{F}^{2}$ is a non-linear term and $\alpha_{3}$ measures the effect of $\mathrm{F}^{2}$ on economic growth conditional on its own value. $X_{i t}$ is the vector of other variables that might affect the dependent variable; $y$ measures the marginal effect of $\mathrm{X}_{\mathrm{it}}$ on dependent variable; $i$ and $t$ are country and time indices respectively. $\mathrm{E}$ is the random error term.

\section{The following data was obtained from the above studies}

1. Information on Bibliography - Bibliographical information of each study such as name of the first author, year of publication of study, type of study (published or unpublished), university of the first author was obtained.

2. Study characteristics - Study characteristics such as study type, study design, kind of data used, information on dependent and independent variables such as their functional form and data sources was obtained.

3. Estimation methods used - Data on estimation techniques such as ordinary least squares methods, panel data techniques, time series techniques, instrumental variable techniques and others were obtained.

4. Outcome - Data on outcome variable such as estimated parameters for all independent variables, $t$ values, standard errors, $\mathrm{p}$ values, $\mathrm{z}$ values, $\mathrm{F}$ values of the estimates for linear, non-linear and interaction terms was obtained.

In order to allow for meaningful comparison across different models, partial correlation was used a standard measure. It is calculated using the formula $r=\left[t / \sqrt{ }\left(t^{2}+\right.\right.$ dof $)$. where, $t$ stands for $t$-statistics of the multiple regression coefficient and dof stands for the degrees of freedom of the respective $\mathrm{t}$-statistic.

Modelling simple and meta-regression analysis 
Modelling simple and meta-regression analysis

The following equation is used for simple meta-regression analysis for estimating the overall effect after correcting for publication bias ${ }^{1}$ :

$$
r_{i j}=\beta_{0}+\beta_{1} S_{i j}^{2}+\varepsilon_{i j}
$$

The following equation is used for multiple meta-regression analysis for estimating the overall effect after correcting for publication bias:

$$
\mathrm{r}_{\mathrm{ij}}=\beta_{0}+\beta_{1} \mathrm{SE}_{\mathrm{ij}}^{2}++\beta_{2} \mathrm{X}_{\mathrm{ij}}+\varepsilon_{\mathrm{ij}}
$$

The following equation is used for multiple meta-regression analysis with study and journal specific moderator variables.

$$
\mathrm{r}_{\mathrm{ij}}=\beta_{0}+\beta_{1} \mathrm{SE}_{\mathrm{ij}}^{2}+\beta_{2} \mathrm{X}_{\mathrm{ij}}+\beta_{3} Z_{\mathrm{j}}+\varepsilon_{\mathrm{ij}}
$$

$\mathrm{i}=$ estimate

$\mathrm{j}=$ journal

$\mathrm{r}=$ partial correlation coefficient

$\mathrm{SE}=$ standard error

$\mathrm{SE}^{2}=$ squared standard error

$\beta_{0}=$ shows the genuine effect of governance on growth after correcting for publication bias

$\beta_{1}=$ coefficient of $\mathrm{SE}^{2}$

$\beta_{2}=$ coefficient of other factors such as real world

$\beta_{3}=$ coefficient of study and author related factors

$\varepsilon_{\mathrm{i}}=$ error term

$\mathrm{X}=$ estimate specific covariates

$\mathrm{Z}=$ journal specific covariates

It is worth highlighting at this point that while some studies have defined $r$ on a scale of $0-1$ from low to high governance, others have used it as $0-1$ high to low governance. In order to aggregate estimates, we have rescaled all estimates as $0-1$ low to high governance ${ }^{1}$. This was done by inversing and multiplying both coefficients and standard errors of estimates defined on the opposite scale (i.e. 0-1 high - low governance) by -1 .

\section{Literature Review}

\subsection{Theoretical View on Governance and Growth}

While the role of physical resources and human resources on economic growth cannot be undermined, institutions or economic governance plays an equally important role. Good governance in the form of rule of law, less political instability, low levels of corruption, necessary government effectiveness, high regulatory quality and appropriate levels of voice and accountability maximises economic incentives, reduces both information asymmetry and transaction costs. These contribute towards efficient allocation of resources and add to the smooth functioning of markets. This in turn encourages both domestic and foreign investors to invest

\footnotetext{
${ }^{1}$ Publication bias is tested using Funnel Asymmetric Test (FAT) and Precision Effect Test (PET). FAT-PET is estimated using equation $t_{i}=\beta 1+$ $\beta 0\left(1 / \mathrm{SE}_{\mathrm{i}}\right)+\mathrm{v}_{\mathrm{i}}\left(\right.$ where FAT is $\mathrm{H}_{0}: \beta 1=0$ and PET is $\left.\mathrm{H}_{0}: \beta 0=0\right)$.
}

further and also improves the confidence levels of existing investors. Overall, by building appropriate policies and laws governance builds all the necessary elements for the smooth functioning of markets and thereby contributes towards economic growth (Kaufmann et al, [35]; Busse and Groizard, [6]; Khamfula, [34]).

Theoretically, the relationship between economic governance and economic growth can be explained using North [44]'s institutional framework. In view of this framework, institutions are important in shaping overall performance and growth of economies. Institutions in the form of political, economic and structural interactions are human-made constraints which aim to decrease the level of uncertainty and allow for firms and individuals to interact efficiently. Such an interaction can lead to effective and efficient allocation of resources that can add to economic growth. However, when these institutions function inefficiently it increases the transaction costs and hence discourages economic activities. In this context economic governance can be seen as an institutional factor which can either have a progressive or regressive effect on economic growth (Dahlstrom and Johnson, [13]).

\subsection{Empirical View on Governance and Growth}

To date there has been a growing body of empirical literature that has examined the link between measures of governance and economic growth. These studies have provided continuous debate on the effects of various measures of governance and their impact on economic growth. While some studies have provided positive and significant effects of measures of governance, others have provided positive and insignificant, negative and significant, and negative and insignificant effects of such a relationship leading to overall inconclusiveness of results within this field.

Empirical evidence on effects of various measures of governance on economic growth in the case of South and East Asia and Pacific countries between 1980 and 2012 is provided by Adams and Mengistu [1], Anwar and Cooray [4], Butkiewicz and Yanikkaya [7], Butkiewicz and Yanikkaya [8], Campos and Nugent [10], Evans and Rauch [22], Evrensel [23], Fernandez et al. [26], Haggard and Tiede [31], Jalilian et al. [33], Oliva and Rivera-Batiz [45], Goldsmith [30], Feeny [24], Feeny and McGillivray [25], Alonso [3], Busse and Groizard [6], Khamfula [34], Mo [43], Mauro [42], Drury et al. [18], Assiotis and Sylwester [5], Ekanayake and Chatrna [20], Gani [27], Seldadyo et al.[46], Commander and Nikoloski [12], Klein [38] and Law and Habibullah [39].

Interestingly these studies have focused on either one or more governance measures such as voice and accountability, political instability, government effectiveness, corruption, regulatory quality, rule of law and have produced varied results. A brief and systematic summary of key aspects of the empirical studies are presented in appendix 10. It can be noted that differences in methodology, data sets, 
econometric methods and sample countries have produced mixed results. Inconclusiveness in empirical studies calls for a need for meta-regression analysis of these results in order to produce comparable, reliable and verifiable effect of measures of governance on economic growth.

\section{Results}

Empirical results are presented and analysed in this section. To start with, funnel plots and chronological order of estimates are used to offer a vivid picture on the state of empirical knowledge in governance growth studies. This is followed by simple and multiple meta-regression results. An overview of measures of governance and growth meta-regression analysis is summarised in appendix 6 .

Estimates of various measures of governance and growth are plotted on the funnel plot shown in figures. Funnel plot traces the association between the effect size (partial correlation) and its precision (precision is calculated as inverse of standard error). We plot effect size on the $\mathrm{X}$ axis and precision on the $\mathrm{Y}$ axis. Estimates with high precision are normally few and are compactly distributed at the top of the funnel, while estimates with low precision are widely dispersed at the bottom of the funnel. Lack of consensus among estimates usually results in wide dispersion of the estimates and vice versa indicating possible publication bias ${ }^{2}$. Note that the reported estimates of most measures of governance and growth (except for corruption) are widely distributed around the central value of the funnel plot. While such a wide dispersion of values can arise due to real world factors, it can also be due to sampling error and due to differences in the research design (Doucouliagos and Ulubasoglu, [17]). In each of these graphs, the centre of the plot represents the estimated true underlying effect of respective measure on growth.

We also plot chronological order of estimates reported from 1980 on various measures of governance against average year of sample period of each study. In most of the cases (political stability, regulation, law and corruption) an upward trend can be seen in the estimates. While countries in South and East Asia \& Pacific regions had governance well before the 1980's, an upward trend suggests that the effect of governance on growth started after the 1980's. In the case of voice and accountability and government effectiveness, we see fluctuations in estimates over the time period in focus.
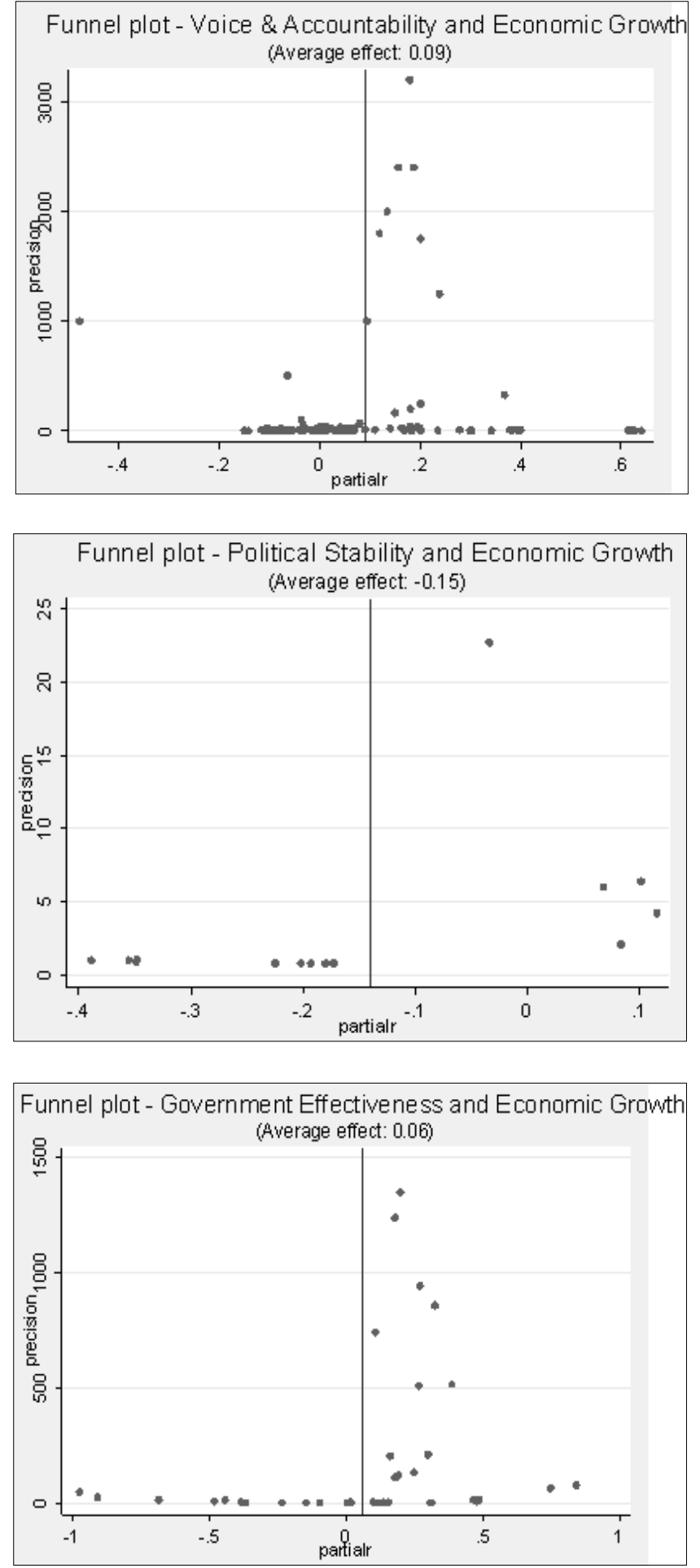

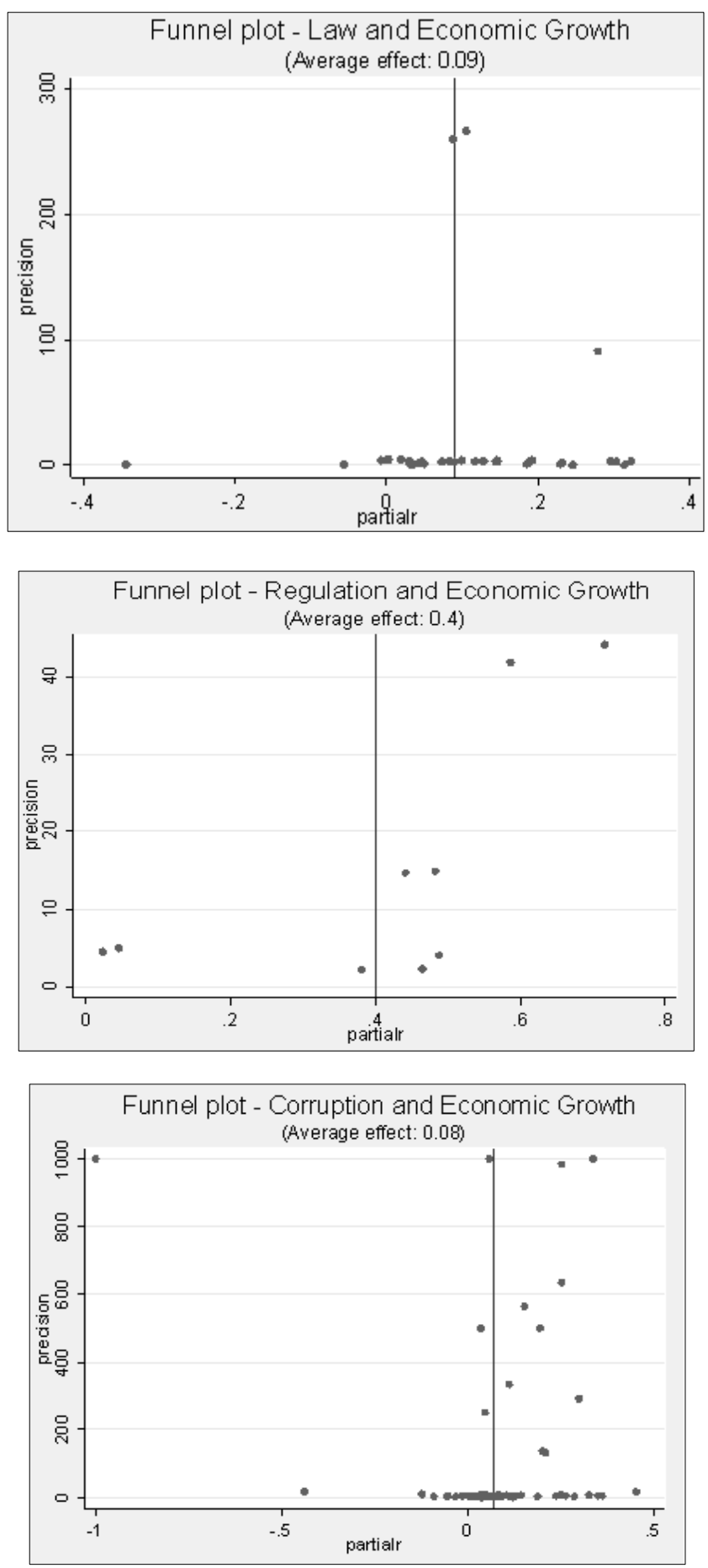

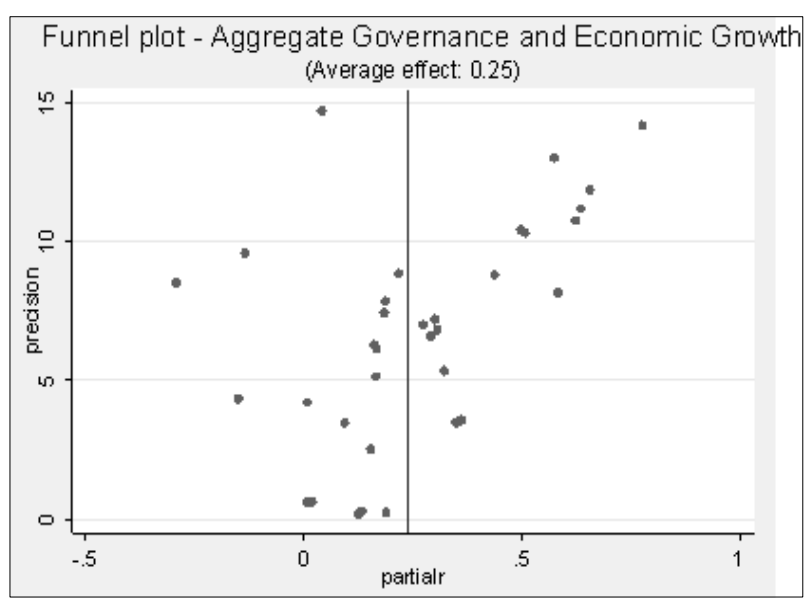

Figure 2. Funnel Plots
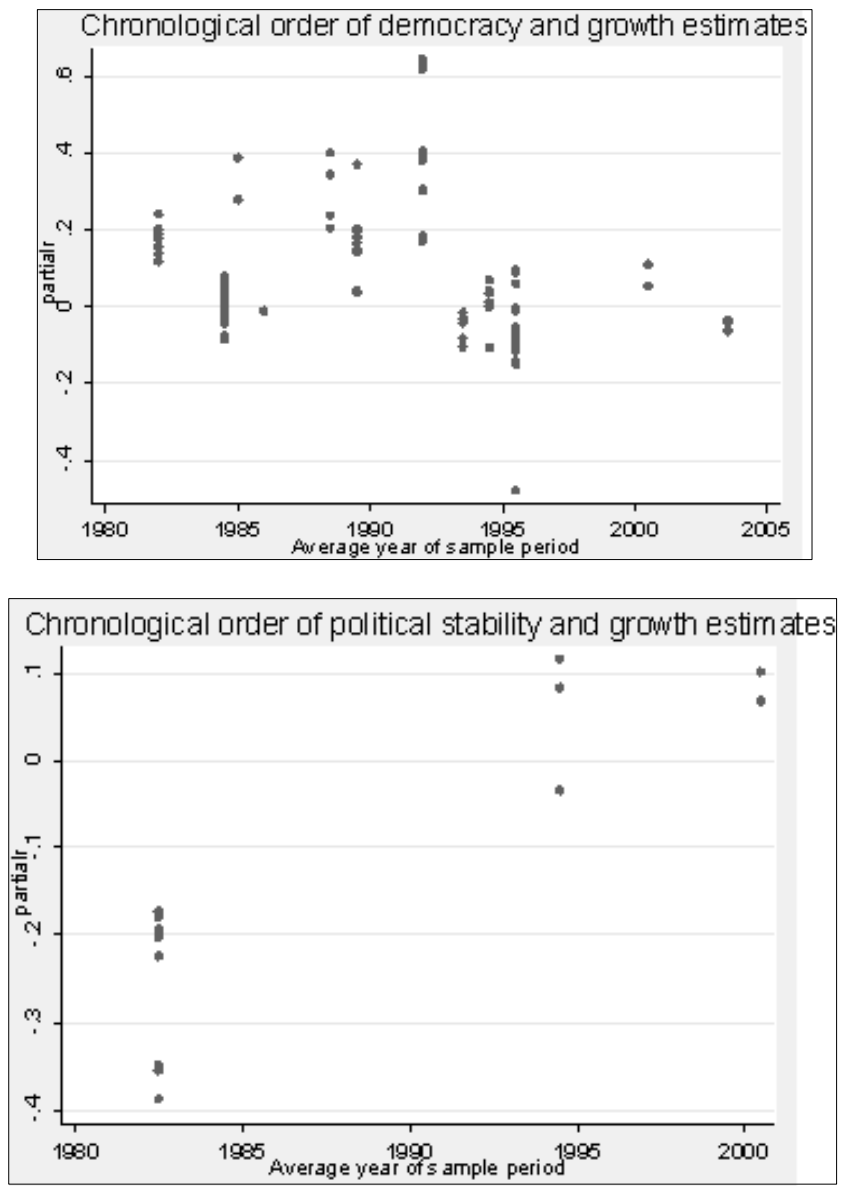

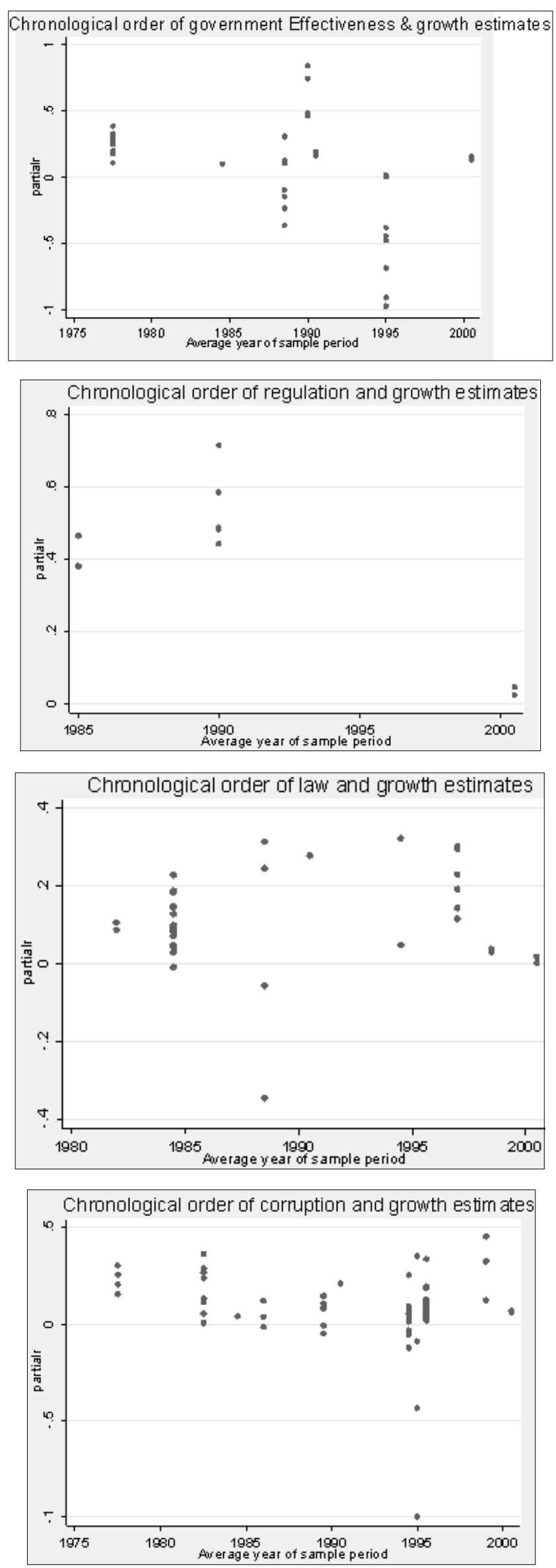

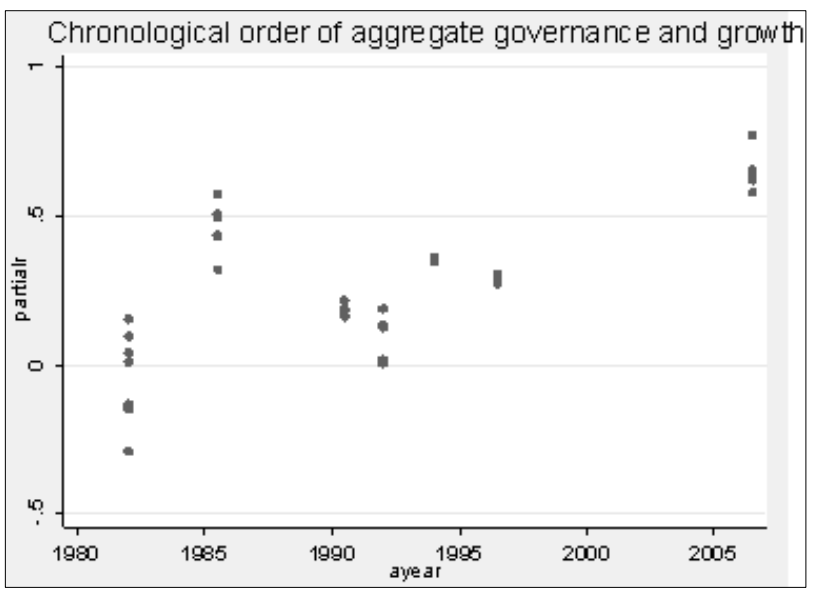

1. Low governance should be interpreted as less democracy, low political stability, less regulation, low levels of government effectiveness, less of rule of law, high corruption and low overall governance.

2. We have tested for publication bias and its genuine effects using Funnel asymmetric test (FAT), Precision effect test (PET). Despite the presence of publication bias, there is genuine effect of these measures on economic growth. We explore these aspects further in a different paper on publication bias in governance-growth studies.

3 . Governance measures are rescaled as $0-1$ high to low corruption. Hence, negative sign should be read as positive effect.

Figure 3. Chronological order of estimates based on average year of sample perio

\subsection{Simple Meta-regression Analysis}

The following table shows simple meta-regression results of various measures of governance on growth. Row1 shows unweighted estimates and row 2 shows weighted least squares estimates, weighted by precision. In the case of unweighted models, voice and accountability, government effectiveness and regulation show a positive effect on growth. Hence, more of these measures is good for economic growth. Due to rescaling of governance measures, although corruption shows a positive sign, it should be interpreted inversely.

Negative effect of corruption indicates that less of this measure has growth enhancing effect. Nevertheless, these results should be interpreted carefully, both due to low $\mathrm{R}^{2}$ values and fewer observations (especially for political stability and regulation measures). Another shortcoming of unweighted method is that it treats all observations with equal weight. This means studies reporting more than one observation can have an undue effect on the overall result.

In order to remove such undue effect, we use the weighted least squares model. Following Stanley and Doucouliagos (2012), weights are calculated as inverse of standard deviation. Once weights are applied, size and sign of a few measures of governance have changed. While law shows a positive effect, positive sign on corruption implies a negative effect. However, $\mathrm{R}^{2}$ values are still small, suggesting that these estimates are unreliable. One reason for lower $\mathrm{R}^{2}$ could be due to the fact that additional variables which can potentially show an effect on growth are not considered. Hence, we run multiple regression analysis including few moderator variables. These results are used to validate simple meta-regression results. 
Table 1. Simple meta-regression results

\begin{tabular}{|c|c|c|c|c|c|c|}
\hline & Political Stability & $\begin{array}{c}\text { Government } \\
\text { effectiveness }\end{array}$ & Regulation & Law & $\begin{array}{c}\text { Corruption } \\
\text { Aggregate } \\
\text { governance }\end{array}$ \\
\hline Un weighted, $\beta 0$ (Row1) & $\begin{array}{c}0.16 \\
(2.41) \\
\left(\mathrm{R}^{2}=0.68\right)\end{array}$ & $\begin{array}{c}0.07 \\
(0.73) \\
\left(\mathrm{R}^{2}=0.00\right)\end{array}$ & $\begin{array}{c}0.26 \\
(1.75) \\
\left(\mathrm{R}^{2}=0.17\right)\end{array}$ & $\begin{array}{c}0.14 \\
(5.81) \\
\left(\mathrm{R}^{2}=0.14\right)\end{array}$ & $\begin{array}{c}0.05 \\
(1.74) \\
\left(\mathrm{R}^{2}=0.05\right)\end{array}$ & $\begin{array}{c}0.39 \\
(6.90) \\
\left(\mathrm{R}^{2}=0.24\right)\end{array}$ \\
\hline $\begin{array}{c}\text { Weighted by precision, } \boldsymbol{\beta 0} \\
\text { (Row2) }\end{array}$ & $\begin{array}{c}0.11 \\
(3.78)\end{array}$ & $\begin{array}{c}0.54 \\
(6.50) \\
\left(\mathrm{R}^{2}=0.64\right)\end{array}$ & $\begin{array}{c}0.89 \\
(5.16)\end{array}$ & $\begin{array}{c}-0.31 \\
(-7.15) \\
\left(\mathrm{R}^{2}=0.67\right)\end{array}$ & $\begin{array}{c}-0.15 \\
(-2.46) \\
\left(\mathrm{R}^{2}=0.15\right)\end{array}$ & $\begin{array}{c}0.65 \\
(13.77) \\
\left(\mathrm{R}^{2}=0.63\right)\end{array}$ \\
\hline Number of estimates & 14 & 36 & 9 & 48 & 78 \\
\hline
\end{tabular}

Note $^{2}$ : Values in parenthesis right below the estimate represent $t$-values. Each column represents models run with all estimates of that measure of governance. Results in case of Regulation and Political Stability are less reliable due to fewer observations (less than 30).

Table 2. Multiple meta-regression results

\begin{tabular}{|c|c|c|c|c|c|c|}
\hline & $\begin{array}{l}\text { Political } \\
\text { Stability }\end{array}$ & $\begin{array}{l}\text { Government } \\
\text { effectiveness }\end{array}$ & Regulation & Law & Corruption & $\begin{array}{c}\text { Aggregate } \\
\text { governance }\end{array}$ \\
\hline $\begin{array}{l}\text { Weighted by } \\
\text { precision, } \beta 0 \\
\text { (Row1) }\end{array}$ & $\begin{array}{c}-0.66 \\
(-1.48) \\
\left.\text { (Adj. } \mathrm{R}^{2}=0.95\right)\end{array}$ & $\begin{array}{c}0.34 \\
(4.77) \\
\left.\text { (Adj. } \mathrm{R}^{2}=0.69\right)\end{array}$ & $\begin{array}{c}0.59 \\
(21.53) \\
\left.\text { (Adj. } \mathrm{R}^{2}=0.99\right)\end{array}$ & $\begin{array}{c}0.06 \\
(0.56) \\
\left.\text { (Adj. } \mathrm{R}^{2}=0.97\right)\end{array}$ & $\begin{array}{c}0.71 \\
(6.96) \\
\left.\text { (Adj. } \mathrm{R}^{2}=0.96\right)\end{array}$ & $\begin{array}{c}0.45 \\
(4.64) \\
\left.\text { (Adj. } \mathrm{R}^{2}=0.92\right)\end{array}$ \\
\hline $\begin{array}{l}\text { Cluster } \\
\text { analysis } \\
\text { (Row2) }\end{array}$ & $\begin{array}{c}-0.66 \\
(-2.48) \\
\left(\mathrm{R}^{2}=0.96\right)\end{array}$ & $\begin{array}{c}0.34 \\
(45.8) \\
\left(\mathrm{R}^{2}=0.72\right)\end{array}$ & $\begin{array}{c}0.59 \\
(4627) \\
\left(\mathrm{R}^{2}=0.99\right)\end{array}$ & $\begin{array}{c}0.06 \\
(0.97) \\
\left(\mathrm{R}^{2}=0.98\right)\end{array}$ & $\begin{array}{c}0.71 \\
(22.75) \\
\left(\mathrm{R}^{2}=0.96\right)\end{array}$ & $\begin{array}{c}0.45 \\
(12.82) \\
\left(\mathrm{R}^{2}=0.93\right)\end{array}$ \\
\hline $\begin{array}{l}\text { No. of } \\
\text { estimates }\end{array}$ & 14 & 36 & 9 & 48 & 78 & 36 \\
\hline
\end{tabular}

Note: Values in parenthesis right below the estimate represent t-values. Each column represents models run with all estimates of that measure of governance.

\footnotetext{
${ }^{2}$ Results of Precision Effect Test (PET) suggests that there is no true effect of voice and accountability beyond publication bias. Hence, we conclude that empirical research on this measure of governance has failed to provide true effect of voice and accountability on growth.
} 


\subsection{Multiple Meta-regression Analysis}

We include the following moderator variables in multiple regression analysis. These variables are chosen as they are potentially important and some of which have been found to be significant in earlier meta-analysis studies (Doucouliagos \& Paldam [15], [16]; Doucouliagos \& Ulubasoglu [17]).

In terms of study related aspects we control for differences and whether or not a study is published, estimation techniques used by the studies, data related aspects such as the kind of data used (panel, time series and cross sectional data), whether or not studies report observations, and data sources for both governance and economic growth. In real world factors, we see regional effects by classifying the estimates into those belonging to South Asia, East Asia, South East Asia and others. We also use dummy variables for China and South Korea to see if inclusion of these variables makes any difference to results reported.

We wish to test if author related aspects such as the university of the first author. Based on this, we classify authors into American, European, South \& East Asian and others. Journal related aspects such as journal discipline and ranking are controlled. Based on discipline, journals are classified into Economics \& Finance, Business Management, Law, Science \& Technology, Geography, Policy and Development. ABS 2010 journal rankings $1^{*}, 2^{*}, 3^{*}$ and $4^{*}$ are used to test if the future ranking of journal has any impact on results. While most of the study and real world related factors are proven to be important in earlier meta-regression studies, we merely wish to test the effects of journal and author related aspects. Main meta-regression results are presented in table 2 and the effect of moderator variables is shown in appendix 7.

The above table displays the results of multiple meta-regression analysis for each measure of governance except for voice and accountability, and regulation. Row1 shows weighted least squares estimates and row 2 shows results of multiple regression analysis clustered by study. Under cluster analysis, each study is seen as a separate cluster and therefore the number of estimates of each study become the number of observations of each cluster (Doucouliagos and Ulubasoglu [17]; Doucouliagos et al. [14]). Results in row 2 are used as a robustness check for the WLS results shown in row 1.

In the case of voice and accountability, we conclude that research literature has failed to provide evidence of true effect of it on growth. One would expect that either governance in the form of high levels of voice and accountability enhance economic growth as opposed to lower levels of voice and accountability or vice versa.These results are contrast to results reported by Anwar and Cooray [4], Campos and Nugent [10] and Oliva and Rivera-Batiz [45]. These results are also different to meta-regression results reported by Doucouliagos and Ulubasoglu [17] for a broader group of countries in the world, which indicate that voice and accountability has no effect on economic growth.

Surprisingly, political stability shows a negative and insignificant effect on economic growth. Hence, it can be deduced that political stability does not matter for economic growth. One would expect that stable and long term governments are good for growth. Positive effect can be realised when political stability removes uncertainty associated with uncertain political environment and increase investments along with the pace of economic growth. Despite this, there might be two possibilities where such a stability does not have such a positive effect. Firstly, if the political stability is achieved through oppression, it might show a negative effect on growth. Secondly, when political stability precludes any form of change and leads to some sort of stagnation that does not allow competition in economic activity. While this study does not examine the reasons for such insignificant effect, it is worthy of future research to focus on these aspects. These results must be interpreted with caution for two reasons. Firstly, because of fewer number of observations and secondly, as these results are not confirmed by cluster analysis.

Government effectiveness shows a positive, robust and statistically significant effect on growth. These findings are in line with those reported by Jalilian et al. [33]. It is worth noting that government effectiveness measures have aggregated all studies that have looked at the effect of measures of governance such as quality of civil and public service, existence of red tape, quality of policy formulation and implementation and government's credibility to its stated policies. As one would expect that countries with better government effectiveness achieve high growth rates through high credit ratings and investments, it is not surprising to see such positive effects. This leaves scope for future research to examine those variables of government effectiveness that show a positive effect on economic growth and to differentiate them from those that cause negative effect.

Regulation is found to show a positive, robust and statistically significant effect on economic growth. In comparison to less regulated countries, my results indicate that highly regulated economies witness higher levels of economic growth. While these results are in line with institutionalist's view that tighter regulation promotes economic growth, and it does not compare with other studies such as those by Goldsmith [30] and Gani [27]. However, these results must be interpreted with caution because of fewer number of observations (less than 30). As most of the countries in this region have deregulated their economies post 1980's with the aim of removing the regulatory burden as well as to promote their economies (Jalialian et al., [33]), these results are not surprising. Similar to government effectiveness, it is important to note that empirical studies included under this measure have focused on various forms of regulations such as accounting and environmental among many others. It could be possible that any one form of the above regulations is showing positive effect on growth and not others. This study only offers an overview on the effect of regulation on growth and 
does not focus on individual forms of it.

In contrast with the results reported by Ugur and Dasgupta [50], Campos et al., [9] and Mauro [42], Butkiewicz and Yanikkaya [7], Evrensel [23], Drury et al., [18] and Gani [28], this study finds negative, robust and statistically significant effect of corruption on economic growth. A positive sign on this measure should be read as corruption, having growth retarding effects ${ }^{3}$. This supports widely held views that corruption is detrimental to economic growth as it can create obstacles dissuading productive activities. Results of this study contradict the view that corruption aids economic growth by 'greasing the wheels' of economic activity.

Although, the present study does not consider various forms and types of corruption, it is worth noting that certain forms of corruption are considered to be acceptable from growth point of view, while others are not (Leff [40]). Hence, it is possible that the overall negative effect of corruption is caused due to more of unacceptable forms of corruption. For instance, if bribes are paid to government officials to overcome bureaucratic delays in starting business and any inefficient rules associated with them, then allowing such corruption will facilitate investments and have a beneficial effect on economic activity (Leff [40]; Huntington [32] and Lui [41] are good papers to read on how corruption enhances economic growth). A negative effect here suggests that this might not be the case. In order to suggest appropriate policy intervention within this area, further research is strongly advised especially to segregate the effects of different forms of corruption on growth.

One would either expect law to promote economic growth through various routes such as protection of property rights, institutional checks on government or by mitigating violence; (Haggard and Tiede [31] is a good paper to read more on this) or to have detrimental effects on growth through tighter laws. However, my study reveals that law is less important for economic growth. The insignificant effect of law on growth is in contrast to positive and significant effects reported by Easterly [19], Kaufmann et al [35], Fernandez et al. [26], Kaufmann et al [36] and Busse and Groizard [6]. Similar to the corruption measure of governance, our results in the case of law are not robust to cluster analysis.

As expected, overall governance also shows a positive and significant effect on growth. The positive effect of aggregate governance on growth was expected as most of the individual measures of governance showed positive effect (except for corruption measure). As good governance is expected to be a prerequisite for economic growth by providing a favourable climate for investments and other economic activities, these results are not surprising (Globerman and Shapiro [29]). Hence, it can be inferred that, governance in these regions is serving as a helping hand for growth through less cumbersome and friendly rules and regulations, and by appropriate enforcement of law. These results are in line with the Dunning's OLI paradigm and institutionalist's view that institutions need not necessarily deter economic growth, they can instead aid it.
All the above results must be read and interpreted carefully by duly taking into account the following points. Firstly, while on one hand the results on government effectiveness, regulation, law, corruption and aggregate governance are robust to cluster analysis, on the other hand results are not robust in the case of political stability. Secondly, while results on some measures of governance can be a bit surprising and unexpected, it is important to note that we do not have sufficient region specific estimates to see if these results are more specific to one region than others (i.e. East Asia or South East Asia or South Asia). Thirdly, we do not have sufficient estimates controlling for endogeneity to check if the results show genuine effect of governance measures on growth or whether the effect is due to causality. Finally, while our results are reliable with high $\mathrm{R}^{2}$ value and econometrically sufficient observations, in the case of government effectiveness, corruption, law and aggregate governance, they are less reliable for regulation and political stability due to fewer observations (less than 30 ).

\subsection{Heterogeneity Analsis}

We now turn my attention towards exploring the factors that have caused heterogeneity in reported results of governance and growth studies. While we have included many study, real world, author and journal related factors, only few study, author and journal related factors proved to be important.

Many study related factors have proven to make a significant difference to reported results. We find that governance effect varied based on the data type used. For instance, Regulation studies using panel data have reported lesser effects compared to those using cross sectional data. Studies focusing on political stability, regulation and law measures of governance and those using yearly data on growth have reported higher effects compared to those using non-yearly data. As opposed to the notion that governance takes long time to show its effect on growth, these results suggest that political stability, regulation and law have quicker effects.

Studies including population related variable have reported higher effects of law and lower effects of overall governance on growth. Those including domestic investment have reported higher effects of aggregate governance on growth. We infer from these results that omitted variable bias does matter for governance and growth studies. Governance and growth sources did matter. For instance, studies using governance data from Polity and ICRG have reported lower effects of political stability and aggregate governance respectively on growth. This suggests that either these measures are under reporting the effect on growth as they are merging many but similar sources, or else other sources are over reporting the effect. Differences in defining FDI and growth did not make any difference to the stated results.

Our study provides evidence that real world related factors did matter for governance growth studies. Models 
including South Korea in their list of sample countries conveyed bigger effects of overall governance on growth. Author and journal characteristics did make a difference in governance and growth studies. European authors have emphasised less on regulation and law measures compared to other authors. As we expected, the rest of the author and journal related aspects such as authors from 'best' universities and journal ranking did not matter.

\section{Concluding Remarks}

This paper has meta-synthesised the empirical evidence on various measures of governance and economic growth in South and East Asia Pacific countries based on 29 studies with 554 estimates from $1980-2012$. The empirical results show that while corruption is significantly and negatively correlated with growth, government effectiveness and regulation are positively and significantly correlated. Political stability and law have no important effect on economic growth. We find no effect of voice and accountability after correcting for publication bias. Finally, overall governance is important for growth. As the results with respect to law and political stability are unexpected, it raises questions on whether these measure of actually measure what they have to measure. Various study, real world, estimation and author related aspects proved to have made difference to the stated results.

The main limitations of this study are as follows. Firstly, this study has focused only on South and East Asia and Pacific countries from $1980-2012$. As the results of this study are confined to empirical results on measures of governance on growth during this period, they represent the research at one point in time and cannot be used as a forecasting tool. Another possible caveat of the research is that we have only focused on calculating the direct effects of measures of governance on economic growth. This study did not analyse the indirect effects of measures of governance on economic growth through their interaction with other physical and macro environment factors. To a large extent this has been due to the limited number of interaction and nonlinear terms of measures of governance. As an example, there were only 9 estimates of government effectiveness through regulation. Finally we would like to comment on the matter of the type of empirical studies included in our study. One of the main criteria in including a study has been that the measure of governance in the primary studies is expressed as a scale and not as a number (i.e. number of assassinations, number of riots amongst many others).

Few aspects of this study that require further research are identified. First, empirical studies on measures of governance and economic growth are relatively few in the case of South and East Asia and Pacific countries as opposed to studies on other determinants of growth. While one reason for this could be the unavailability of data in the past, recent years have seen a surge in data sources. More specifically, World Bank's project on worldwide governance indicators provides governance data on different measures of governance for 212 countries from 1996 onwards. Future research can make use of this data and conduct further research. In addition to this, as there is a possibility of reverse causality between measures of governance and growth, there is a need for controlling this aspect as well.

Secondly, most of the governance indicators used by the primary studies have used people's perceptions of governance in various countries derived from polls, surveys or expert opinions (with the exception of Busse and Groizard [6] who uses objective data on regulation from the Doing Business database provided by World Bank (2006)). These measures are predominantly taken from sources such as Polity data set, ICRG and others. Such perception based measures are subjective and lack objective analysis of governance in addition to leading to a large margin of error (Gani [28]). Hence, future researchers can use more reliable and objective data on institutions to measure their effect on economic growth or find weighted measures of governance by combining perception based data on measures of governance with that of objective data (Ugur and Dasgupta [50]).

Thirdly, an important issue for future research concerns the indirect effects of measures of governance. Governance measures can transmit indirect effects on growth through factors such as human capital, physical capital amongst many other factors. Our systematic search for empirical studies has found 12 out of 26 studies measuring such indirect effects. Governance measures are interacted with factors like domestic credit, private credit, capital account, money supply, bank market concentration amongst others. Due to the diverse nature of interaction terms and the limited number of observations under each category, we did not include them in my meta-regression analysis. This shows a clear scope for inclusion of indirect effects of governance on growth by future studies. In the fourth instance, the systematic literature review approach should have taken into account general macro trends. As we are relying on studies that have not taken on board macro-economic trends and related aspects such as the effect of structural adjustment program, the effect of governance might not reflect the true effect. The final important area where additional research is required is on the use of time series data. Authors of primary studies have mainly focused on panel studies (except Feeny [24]). While panel studies help in getting more robust and econometrically efficient results, country specific studies will help in exploring country specific effects of various measures of governance on growth.

Based on the results of this study, I am convinced that without establishment and maintenance of economic governance in an appropriate manner, achieving economic growth might be difficult. My results have important policy implications. As a preface, it is important to point out that while any attempts by governments to enhance economic growth must focus on all measures of economic governance, some measures should be tighter than others. Policy implications of the results for South and East Asia \& Pacific 
countries are that they can enhance their economic growth by improving governance, particularly by brining improvements in government effectiveness and regulation.

While corruption is found to have a negative effect on the growth, my study does not suggest exact channels or forms through which it affects economic growth. Nevertheless, if assuming causes of corruption are to cut down efficient rules, then policy intervention aimed at reducing such corruption is suggested. This will bring down the levels of corruption as well as enhance economic growth. More growth friendly governance in terms of improving regulatory quality and government effectiveness through reforms to their fundamental governance frameworks is also advised.

\section{Appendix}

\section{Search keywords used in governance and growth meta-regression analysis}

Keywords for economic governance

Corporate governance OR Governance or economic governance or worldwide governance indicators OR Voice and Accountability OR Political Stability and Absence of Violence OR Government Effectiveness OR Regulatory Quality OR Rule of Law OR Control of Corruption OR

Bureaucracy

Keywords for economic growth

Growth or economic growth or development or economic performance or investment or labour productivity or capital or innovation or labour market participation or progress or expansion or increase or improvement or advance or spill over effects or efficiency

Keywords for South and East Asia \& Pacific countries

Emerging economies OR East Asian economies OR South east Asian economies OR East Asia OR South Asia OR South east Asia OR Afghanistan OR Bangladesh OR Bhutan OR India OR Maldives OR Nepal OR Pakistan OR Sri Lanka OR American Samoa OR Cambodia OR China OR Fiji OR Indonesia OR Kiribati OR Korea, Dem. Rep. OR Lao PDR OR Malaysia OR Marshall Islands OR Micronesia, Fed. Sts OR Mongolia OR Myanmar OR Palau OR Papua New Guinea OR Philippines OR Samoa OR Solomon Islands OR Thailand OR Timor-Leste OR Tuvalu OR Tonga OR Vanuatu OR Vietnam OR ASEAN OR Developing economies OR Developing countries OR South Korea OR Republic of Korea

\section{PIOS framework}

Population - The study should focus on South and East Asia Pacific economies or equivalent as specified in the search criteria.

Independent variable - The study should be examining the impact of measures economic governance in terms of a scale or its equivalent as specified in the search criteria.

Outcome variable - The study should be examining economic growth or as defined in the search criteria.

Study design - Study design can be either theoretical or empirical. A study is considered to be theoretical if it is based on some theoretical model drawing verbal or mathematical conclusions analysing impact of economic governance on economic growth. A study is considered to be empirical if it is based on regression model and draws an estimation model to estimate economic governance on economic growth.

\section{Number of empirical studies satisfying PIOS criteria}

\begin{tabular}{|r|c|}
\hline \multicolumn{1}{|c|}{ Criteria } & Number of studies satisfying the criteria \\
\hline Population (South and East Asia \& Pacific countries) & 32 \\
\hline Independent variable (Measures of governance) & 29 \\
\hline Outcome variable (Economic growth) & 18 \\
\hline Study design - Empirical & 32 \\
\hline Decision Select if all 4 criteria match - PIOS & 20 \\
\hline Select for next stage & 71 \\
\hline
\end{tabular}




\section{Descriptive statistics of moderator variables}

\begin{tabular}{|c|c|c|c|}
\hline $\begin{array}{c}\text { Moderator } \\
\text { variable }\end{array}$ & Definition & Mean & $\begin{array}{l}\text { Standard } \\
\text { deviation }\end{array}$ \\
\hline Ptype1 & $=1$ if the estimate is taken from an article that is published in a journal & 0.676 & 0.47 \\
\hline Ptype2 & $=1$ if the estimate is taken from unpublished study (working paper or discussion paper) & 0.324 & 0.47 \\
\hline Obsgiven & $=1$ if the estimate is taken from a model in which observations are reported & 0.956 & 0.20 \\
\hline Obstaken & $=1$ if the estimate is taken from a model in which observations are not reported & 0.044 & 0.20 \\
\hline Gov1 & $\begin{array}{l}=1 \text { if the estimate belongs to model which defined governance in terms of voice and } \\
\text { accountability }\end{array}$ & 0.267 & 0.44 \\
\hline Gov2 & $\begin{array}{l}=1 \text { if the estimate belongs to model which defined governance in terms of political } \\
\text { stability }\end{array}$ & 0.025 & 0.16 \\
\hline Gov3 & $\begin{array}{c}=1 \text { if the estimate belongs to model which defined governance in terms of government } \\
\text { effectiveness }\end{array}$ & 0.065 & 0.25 \\
\hline Gov4 & $=1$ if the estimate belongs to model which defined governance in terms of regulation & 0.016 & 0.13 \\
\hline Gov5 & $=1$ if the estimate belongs to model which defined governance in terms of law & 0.087 & 0.09 \\
\hline Gov6 & $=1$ if the estimate belongs to model which defined governance in terms of corruption & 0.142 & 0.35 \\
\hline Govall & $\begin{array}{c}=1 \text { if the estimate belongs to model which defined governance in terms of aggregate } \\
\text { governance }\end{array}$ & 0.065 & 0.25 \\
\hline Data1 & $=1$ if the estimate is taken from model that has used yearly data on growth & 0.62 & 0.49 \\
\hline Data2 & $=1$ if the estimate is taken from model that has used non-yearly data on growth & 0.38 & 0.49 \\
\hline Dtype1 & $=1$ if the estimate is taken from a model that has used panel data & 0.815 & 0.39 \\
\hline Dtype2 & $=1$ if the estimate is taken from a model that has used time series data & 0.018 & 0.13 \\
\hline Dtype3 & $=1$ if the estimate is taken from a model that has used cross sectional data & 0.167 & 0.37 \\
\hline Countryl & $\begin{array}{c}=1 \text { if the estimate belongs to a model that has used data on FDI and measure of } \\
\text { governance of South East Asia }\end{array}$ & 0.018 & 0.13 \\
\hline Country2 & $\begin{array}{c}=1 \text { if the estimate belongs to a model that has used data on FDI and measure of } \\
\text { governance of South Asia }\end{array}$ & 0.047 & 0.21 \\
\hline Country3 & $\begin{array}{l}=1 \text { if the estimate belongs to a model that has used data on FDI and measure of } \\
\text { governance of East Asia }\end{array}$ & 0.051 & 0.22 \\
\hline Country4 & $\begin{array}{l}=1 \text { if the estimate belongs to a model that has used data on FDI and measure of } \\
\text { governance of mixed countries }\end{array}$ & 0.884 & 0.32 \\
\hline Method1 & $=1$ if the estimate belongs to a model that is estimated using OLS techniques & 0.471 & 0.50 \\
\hline Method2 & $=1$ if the estimate belongs to a model that is estimated using panel data techniques & 0.276 & 0.45 \\
\hline Method3 & $\begin{array}{c}=1 \text { if the estimate belongs to a model that is estimated using instrumental variable } \\
\text { techniques }\end{array}$ & 0.147 & 0.36 \\
\hline Method4 & $=1$ if the estimate belongs to a model that is estimated using time series techniques & 0.018 & 0.13 \\
\hline Method5 & $=1$ if the estimate belongs to a model that is estimated using other techniques & 0.087 & 0.28 \\
\hline Dumchil & $\begin{array}{l}=1 \text { if the estimate belongs to a model that has included China in the list of sample } \\
\text { countries }\end{array}$ & 0.675 & 0.47 \\
\hline Dumchi2 & $\begin{array}{l}=1 \text { if the estimate belongs to a model that has excluded China from the list of sample } \\
\text { countries }\end{array}$ & 0.325 & 0.47 \\
\hline Dumsk1 & $\begin{array}{c}=1 \text { if the estimate belongs to a model that has included South Korea in the list of sample } \\
\text { countries }\end{array}$ & 0.716 & 0.45 \\
\hline Dumsk2 & $\begin{array}{c}=1 \text { if the estimate belongs to a model that has excluded South Korea from the list of } \\
\text { sample countries }\end{array}$ & 0.284 & 0.45 \\
\hline Journal1 & $\begin{array}{c}=1 \text { if the estimate is taken from a journal that belongs to Economics and Finance } \\
\text { discipline }\end{array}$ & 0.727 & 0.45 \\
\hline Journal2 & $\begin{array}{c}=1 \text { if the estimate is taken from a journal that belongs to Business Management } \\
\text { discipline }\end{array}$ & 0.018 & 0.13 \\
\hline Journal3 & $=1$ if the estimate is taken from a journal that belongs to Policy discipline & 0.027 & 0.16 \\
\hline Journal5 & $=1$ if the estimate is taken from a journal that belongs to Development discipline & 0.227 & 0.42 \\
\hline Lauthor1 & $=1$ if the first author of the study is from American University & 0.331 & 0.47 \\
\hline Lauthor2 & $=1$ if the first author of the study is from European University & 0.42 & 0.49 \\
\hline Lauthor3 & $=1$ if the first author of the study is from South \& East Asian University & 0.049 & 0.22 \\
\hline Lauthor4 & $=1$ if the first author of the study is from other Universities & 0.2 & 0.40 \\
\hline Omv1 & $=1$ if the estimate is taken from a model that has included population variable & 0.48 & 0.50 \\
\hline Omv2 & $=1$ if the estimate is taken from a model that has included domestic investment variable & 0.169 & 0.38 \\
\hline Omv3 & $=1$ if the estimate is taken from a model that has included education variable & 0.413 & 0.49 \\
\hline
\end{tabular}




\begin{tabular}{|l|c|c|c|}
\hline Govsource1 & $=1$ if the estimate is estimated using governance data from Freedom House database & 0.298 & 0.46 \\
\hline Govsource & $=1$ if the estimate is estimated using governance data from International Country Risk \\
Guide database & $=1$ if the estimate is estimated using governance data from mixed database & 0.236 & 0.075 \\
\hline Govsource3 & $=1$ if the estimate is estimated using governance data from other sources & 0.102 & 0.26 \\
\hline Govsource4 & $=1$ if the estimate is estimated using governance data from Polity database & 0.136 & 0.30 \\
\hline Govsource 5 & $=1$ if the estimate is estimated using governance data from Transparency International \\
\hline database & 0.02 & 0.34 \\
\hline Govsource6 & $=1$ if the estimate has used governance data from World Governance Indicators from & 0.132 & 0.34 \\
\hline Grosource1 & $=1$ if the estimate has used growth data from International Monetary Fund database & 0.098 & 0.35 \\
\hline Grosource2 & $=1$ if the estimate has used governance data from other databases & 0.144 & 0.35 \\
\hline Grosource3 & $=1$ if the estimate has used governance data from Penn World database & 0.262 & 0.44 \\
\hline Grosource4 & $=1$ if the estimate has used governance data from World Bank database & 0.496 & 0.50 \\
\hline Rank101 & $=1$ if the estimate is taken from a journal that is ranked as 1* in ABS 2010 ranking & 0.044 & 0.21 \\
\hline Rank102 & $=1$ if the estimate is taken from a journal that is ranked as 2* in ABS 2010 ranking & 0.296 & 0.46 \\
\hline Rank103 & $=1$ if the estimate is taken from a journal that is ranked as 3* in ABS 2010 ranking & 0.610 & 0.49 \\
\hline Rank104 & $=1$ if the estimate is taken from a journal that is ranked as 4* in ABS 2010 ranking & 0.051 & 0.22 \\
\hline
\end{tabular}

\section{Summary of governance and growth empirical studies}

\begin{tabular}{|c|c|c|c|c|c|c|}
\hline Study and year & Time period & Countries & Dependent variable & $\begin{array}{l}\text { Independent } \\
\text { variable }\end{array}$ & Findings & Techniques \\
\hline $\begin{array}{c}\text { Adams and } \\
\text { Mengistu (2008) }\end{array}$ & $1991-2002$ & $\begin{array}{l}82 \text { developing } \\
\text { countries }\end{array}$ & $\begin{array}{c}\text { Real GDP growth } \\
\text { rate and Real GDP } \\
\text { per capita } \\
\text { (World Economic } \\
\text { Outlook (2004) and } \\
\text { Global } \\
\text { Development } \\
\text { Network Growth } \\
\text { Database }\end{array}$ & $\begin{array}{l}\text { Governance } \\
\text { (Kaufmann et al. } \\
\text { (2005)) }\end{array}$ & $\begin{array}{c}\text { Positive and } \\
\text { significant effect of } \\
\text { governance on growth }\end{array}$ & $\begin{array}{c}\text { Least squares } \\
\text { dummy variable } \\
\text { approach }\end{array}$ \\
\hline $\begin{array}{c}\text { Anwar and } \\
\text { Cooray (2012) }\end{array}$ & $1970-2009$ & $\begin{array}{l}8 \text { South Asian } \\
\text { countries }\end{array}$ & $\begin{array}{l}\text { Per capita income } \\
\text { (constant } 2000 \\
\text { US\$) } \\
\text { (World } \\
\text { Development } \\
\text { Indicators, 2011) }\end{array}$ & $\begin{array}{c}\text { Democracy } \\
\text { Freedom House } \\
\text { Political Rights } \\
\text { Index and freedom } \\
\text { House Civil } \\
\text { Liberties Index } \\
\text { (Freedom House, } \\
\text { 2011) } \\
\text { Polity IV Index } \\
\text { (Marshall and } \\
\text { Jaggers, 2010) } \\
\end{array}$ & $\begin{array}{l}\text { Positive and } \\
\text { significant even when } \\
\text { interacted with money } \\
\text { supply }\end{array}$ & $\begin{array}{l}\text { Ordinary least } \\
\text { squares method, } \\
\text { Fixed effects, } \\
\text { System GMM }\end{array}$ \\
\hline $\begin{array}{l}\text { Butkiewicz and } \\
\text { Yanikkaya } \\
\text { (2004) }\end{array}$ & $1970-1999$ & $\begin{array}{l}29 \text { developed } \\
\text { and } 85 \\
\text { developing } \\
\text { countries }\end{array}$ & $\begin{array}{c}\text { Real GDP growth } \\
\text { rate } \\
\text { (World } \\
\text { Development } \\
\text { Indicators, 1999) } \\
\text { Initial GDP per } \\
\text { capita } \\
\text { (Penn-World } \\
\text { Table) }\end{array}$ & $\begin{array}{l}\text { Democracy } \\
\text { (Freedom House } \\
\text { and Polity III) } \\
\\
\text { Rule of law } \\
\text { (Easterly, 1999) }\end{array}$ & $\begin{array}{l}\text { Rule of law - positive } \\
\text { and significant effect. } \\
\text { Corruption - negative } \\
\text { and insignificant. } \\
\text { Bureaucracy - positive } \\
\text { and insignificant. } \\
\text { Democracy - positive } \\
\text { and insignificant. }\end{array}$ & $\begin{array}{c}\text { Seemingly } \\
\text { unrelated } \\
\text { regression } \\
\text { technique } \\
\text { (SUR) and/or } \\
\text { three stage least } \\
\text { squares (3SLS) }\end{array}$ \\
\hline $\begin{array}{l}\text { Butkiewicz and } \\
\text { Yanikkaya } \\
\text { (2011) }\end{array}$ & $\begin{array}{l}\text { Two sample } \\
\text { period: } \\
1970-1999 \\
1990-2004\end{array}$ & $\begin{array}{c}\text { Over } 100 \\
\text { developed and } \\
\text { developing } \\
\text { nations }\end{array}$ & $\begin{array}{l}\text { Growth of real } \\
\text { GDP per capita } \\
\text { (World Bank, } \\
\text { 2007) }\end{array}$ & $\begin{array}{c}\text { Rule of law } \\
\text { (Kaufmann et al., } \\
\text { 2007) }\end{array}$ & $\begin{array}{c}\text { Positive and } \\
\text { significant in case of } \\
\text { developing countries } \\
\text { Developed countries - } \\
\text { positive but not } \\
\text { significant } \\
\end{array}$ & $\begin{array}{l}\text { Seemingly } \\
\text { unrelated } \\
\text { regression } \\
\text { (SUR) } \\
\text { technique }\end{array}$ \\
\hline
\end{tabular}




\begin{tabular}{|c|c|c|c|c|c|c|}
\hline $\begin{array}{c}\text { Campos and } \\
\text { Nugent (1999) }\end{array}$ & $\begin{array}{c}108 \\
\text { countries; } 28 \\
\text { East Asian } \\
\text { countries }\end{array}$ & $1982-1995$ & $\begin{array}{l}\text { Average level of } \\
\text { real per capita GDP }\end{array}$ & $\begin{array}{c}\text { Democracy } \\
\text { (Freedom House) } \\
\text { Bureaucratic } \\
\text { quality } \\
\text { (ICRG) } \\
\text { Rule of Law } \\
\text { (ICRG) }\end{array}$ & $\begin{array}{l}\text { Without interaction } \\
\text { terms } \\
\text { Democracy - positive } \\
\text { and significant for all } \\
\text { sample and East Asian; } \\
\text { Bureaucracy - positive } \\
\text { and significant for all } \\
\text { sample, positive and } \\
\text { insignificant - East } \\
\text { Asian; } \\
\text { Rule of Law - Positive } \\
\text { and significant for all } \\
\text { sample, positive and } \\
\text { insignificant for East } \\
\text { Asian } \\
\text { With interaction terms } \\
\text { Only democracy is } \\
\text { positive and significant }\end{array}$ & $\begin{array}{l}\text { Ordinary least } \\
\text { squares method }\end{array}$ \\
\hline Evrensel (2010) & $\begin{array}{l}31 \text { developed } \\
\text { and } 90 \\
\text { developing } \\
\text { countries }\end{array}$ & $1990-2000$ & $\begin{array}{c}\text { Average growth } \\
\text { rate of real GDP } \\
\text { (International } \\
\text { Financial Statistics, } \\
\text { IMF, 2007) }\end{array}$ & $\begin{array}{l}\text { Corruption } \\
\text { (ICRG) }\end{array}$ & $\begin{array}{l}\text { Negative and } \\
\text { significant }\end{array}$ & $\begin{array}{l}\text { Ordinary least } \\
\text { squares method }\end{array}$ \\
\hline $\begin{array}{l}\text { Fernandez, } \\
\text { Gonzalez and } \\
\text { Suarez (2010) }\end{array}$ & 84 countries & $1980-2004$ & $\begin{array}{c}\text { Growth rate of real } \\
\text { per capita GDP } \\
\text { (World Bank) }\end{array}$ & $\begin{array}{l}\text { Rule of law } \\
\text { (Heritage } \\
\text { Foundation } \\
\text { (Freedom)) }\end{array}$ & $\begin{array}{l}\text { Positive and } \\
\text { significant }\end{array}$ & $\begin{array}{l}\text { Ordinary least } \\
\text { squares method } \\
\text { and random } \\
\text { effects }\end{array}$ \\
\hline $\begin{array}{l}\text { Haggard and } \\
\text { Tiede (2011) }\end{array}$ & $\begin{array}{l}74 \\
\text { developing } \\
\text { and } \\
\text { transition } \\
\text { countries }\end{array}$ & $2003-2007$ & $\begin{array}{c}\text { GDP per capita in } \\
1995\end{array}$ & $\begin{array}{c}\text { Corruption } \\
\text { (Transparency } \\
\text { International CPI) } \\
\text { Rule of law } \\
\text { (World Bank and } \\
\text { others) } \\
\end{array}$ & $\begin{array}{l}\text { Both positive and } \\
\text { significant }\end{array}$ & $\begin{array}{c}\text { Two stage least } \\
\text { squares }\end{array}$ \\
\hline $\begin{array}{c}\text { Jalilian, } \\
\text { Kirkpatrick and } \\
\text { Parker (2007) }\end{array}$ & $\begin{array}{l}117 \text { countries } \\
\text { for cross } \\
\text { section } \\
\text { regression } \\
96 \text { countries } \\
\text { for panel } \\
\text { regression } \\
\end{array}$ & $1980-2000$ & $\begin{array}{l}\text { GDP growth per } \\
\text { capita } \\
\text { (World Bank) }\end{array}$ & $\begin{array}{l}\text { Regulatory quality } \\
\text { Government } \\
\text { effectiveness } \\
\text { (Kaufmann et al., } \\
\text { 2005) }\end{array}$ & $\begin{array}{l}\text { Positive and } \\
\text { significant effect }\end{array}$ & $\begin{array}{l}\text { Ordinary least } \\
\text { squares method, } \\
\text { fixed effects and } \\
\text { random effects }\end{array}$ \\
\hline $\begin{array}{c}\text { Oliva and } \\
\text { Rivera-Batiz } \\
(2002)\end{array}$ & $\begin{array}{c}119 \\
\text { developing } \\
\text { countries }\end{array}$ & 1970 - 1994 & $\begin{array}{l}\text { Real per capita } \\
\text { annual growth rate }\end{array}$ & 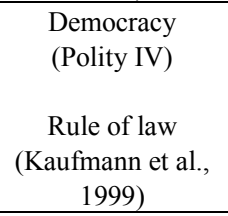 & $\begin{array}{l}\text { Democracy - positive } \\
\text { and significant } \\
\text { Rule of law - positive } \\
\text { and insignificant }\end{array}$ & $\begin{array}{c}\text { Ordinary least } \\
\text { squares method } \\
\text { and Three stage } \\
\text { least squares }\end{array}$ \\
\hline $\begin{array}{l}\text { Goldsmith } \\
\text { (1995) }\end{array}$ & $\begin{array}{l}59 \text { less } \\
\text { developed } \\
\text { and } \\
\text { transitional } \\
\text { countries }\end{array}$ & $1980-1990$ & $\begin{array}{c}\text { Average annual } \\
\text { growth rate of GDP } \\
\text { (IMF, 1994) }\end{array}$ & $\begin{array}{c}\text { Democracy } \\
\text { (Freedom House) } \\
\text { Property rights } \\
\text { index } \\
\text { (Johnson and } \\
\text { Sheehy (1995)) } \\
\end{array}$ & $\begin{array}{l}\text { Both - negative and } \\
\text { significant }\end{array}$ & $\begin{array}{l}\text { Ordinary least } \\
\text { squares method }\end{array}$ \\
\hline Feeny (2005) & 1 country & $1965-1999$ & $\begin{array}{l}\text { GDP growth } \\
\text { (World Bank) }\end{array}$ & $\begin{array}{l}\text { Governance } \\
\text { (ICRG) }\end{array}$ & $\begin{array}{l}\text { Mixed effect but } \\
\text { insignificant }\end{array}$ & $\begin{array}{c}\text { Auto Regressive } \\
\text { Distributed Lag } \\
\text { (ARDL) } \\
\end{array}$ \\
\hline $\begin{array}{l}\text { Feeny and } \\
\text { Mcgillivray } \\
\text { (2010) }\end{array}$ & $\begin{array}{l}29 \text { Small } \\
\text { Island } \\
\text { Developing } \\
\text { States }\end{array}$ & $1980-2004$ & $\begin{array}{l}\text { GDP per capita } \\
\text { growth measured in } \\
\text { constant local } \\
\text { currency units } \\
\text { expressed as a } \\
\text { percentage } \\
\text { (World Bank }\end{array}$ & $\begin{array}{l}\text { Governance } \\
\text { (World Bank) }\end{array}$ & $\begin{array}{l}\text { Positive and } \\
\text { insignificant }\end{array}$ & $\begin{array}{l}\text { Fixed Effects } \\
\text { and GMM }\end{array}$ \\
\hline
\end{tabular}




\begin{tabular}{|c|c|c|c|c|c|c|}
\hline & & & $\begin{array}{c}\text { (2006), Asian } \\
\text { Development Bank } \\
(2006), \text { Grimes } \\
(2000))\end{array}$ & & & \\
\hline Alonso (2010) & 154 countries & $2006-2007$ & $\begin{array}{l}\text { Per capita Income } \\
\text { (Maddison) }\end{array}$ & $\begin{array}{l}\text { Governance index } \\
\text { (World Governance } \\
\text { indicators) }\end{array}$ & $\begin{array}{c}\text { Positive and } \\
\text { significant }\end{array}$ & $\begin{array}{c}\text { Two stage least } \\
\text { squares with } \\
\text { instrumental } \\
\text { variable } \\
\text { technique }\end{array}$ \\
\hline $\begin{array}{c}\text { Busse and } \\
\text { Groizard (2008) }\end{array}$ & 84 countries & $1994-2003$ & $\begin{array}{l}\text { Real growth of } \\
\text { GDP per capita in } \\
\text { per cent } \\
\text { (World Bank, } \\
\text { 2006) }\end{array}$ & $\begin{array}{l}\text { Rule of Law } \\
\text { (PRS Group) }\end{array}$ & $\begin{array}{c}\text { Positive and } \\
\text { significant }\end{array}$ & GMM \\
\hline Khamfula (2007) & 17 countries & $1994-2004$ & $\begin{array}{c}\text { Real GDP } \\
\text { (World Bank) }\end{array}$ & $\begin{array}{l}\text { Corruption } \\
\text { (Corruption } \\
\text { perception Index } \\
\text { from Centre for } \\
\text { Corruption } \\
\text { Research) } \\
\end{array}$ & $\begin{array}{l}\text { Positive and } \\
\text { significant }\end{array}$ & $\begin{array}{c}\text { Ordinary least } \\
\text { squares method }\end{array}$ \\
\hline Mo (2001) & 49 countries & $1970-1985$ & $\begin{array}{l}\text { Growth rate of real } \\
\text { GDP in percentage } \\
\text { (Barro and Lee) }\end{array}$ & $\begin{array}{c}\text { Corruption } \\
\text { (Transparency } \\
\text { International) } \\
\\
\text { Democracy } \\
\text { (Freedom House) } \\
\\
\text { Political stability } \\
\text { (PINSTAB) } \\
\end{array}$ & $\begin{array}{l}\text { Democracy - Positive } \\
\text { and insignificant } \\
\\
\text { Instability - Negative } \\
\text { and significant when } \\
\text { transmission channels } \\
\text { are not included }\end{array}$ & $\begin{array}{c}\text { Ordinary least } \\
\text { squares method, } \\
\text { Two stage least } \\
\text { squares }\end{array}$ \\
\hline Mauro (1995) & 67 countries & $1980-1983$ & $\begin{array}{l}\text { Per capita GDP } \\
\text { growth }\end{array}$ & $\begin{array}{l}\text { Corruption } \\
\text { (Business } \\
\text { International) }\end{array}$ & $\begin{array}{c}\text { Positive and } \\
\text { significant }\end{array}$ & $\begin{array}{c}\text { Ordinary least } \\
\text { squares method, } \\
\text { Two stage least } \\
\text { squares } \\
\end{array}$ \\
\hline $\begin{array}{c}\text { Drury, } \\
\text { Krieckhaus and } \\
\text { Lusztig }(2006)\end{array}$ & $\begin{array}{l}\text { More than } \\
100 \text { countries }\end{array}$ & $1982-1997$ & $\begin{array}{l}\text { Growth of GDP } \\
\text { (World Bank) }\end{array}$ & $\begin{array}{l}\text { Corruption } \\
\text { (ICRG) } \\
\text { Democracy } \\
\text { (Freedom House } \\
\text { and Polity IV) }\end{array}$ & $\begin{array}{l}\text { Corruption - negative } \\
\text { and significant in } \\
\text { non-democratic } \\
\text { countries; positive and } \\
\text { insignificant in } \\
\text { democratic; } \\
\\
\text { Democracy (Freedom } \\
\text { house and polity IV - } \\
\text { negative and } \\
\text { insignificant; positive } \\
\text { and insignificant } \\
\text { (Alvarez, Cheibub, } \\
\text { Limongi and } \\
\text { Przeworski (ACLP) } \\
\text { democracy data)) }\end{array}$ & $\begin{array}{c}\text { Ordinary least } \\
\text { squares method }\end{array}$ \\
\hline $\begin{array}{c}\text { Assiotis and } \\
\text { Sylwester (2012) }\end{array}$ & 119 countries & $1984-2007$ & $\begin{array}{c}\text { Real GDP per } \\
\text { capita } \\
\text { (Penn World Table, } \\
\text { version } 6.3 \text { ) }\end{array}$ & $\begin{array}{c}\text { Democracy } \\
\text { (Freedom House } \\
\text { and Polity Iv) } \\
\\
\text { Corruption } \\
\text { (ICRG and } \\
\text { Transparency } \\
\text { International) } \\
\text { Governance } \\
\text { (World Governance } \\
\text { Indicator) } \\
\end{array}$ & $\begin{array}{c}\text { Corruption and } \\
\text { democracy - positive } \\
\text { and significant } \\
\text { Governance - negative } \\
\text { and significant }\end{array}$ & $\begin{array}{l}\text { System GMM } \\
\text { and Fixed } \\
\text { effects model }\end{array}$ \\
\hline $\begin{array}{l}\text { Ekanayake and } \\
\text { Chatrna (2010) }\end{array}$ & $\begin{array}{c}85 \\
\text { developing } \\
\text { countries }\end{array}$ & $1980-2007$ & $\begin{array}{c}\text { Growth of real } \\
\text { GDP per capita in } \\
\text { constant (2000) US } \\
\text { dollars } \\
\text { (World Bank) }\end{array}$ & $\begin{array}{c}\text { Democracy } \\
\text { (Freedom House) }\end{array}$ & $\begin{array}{c}\text { Negative and } \\
\text { insignificant } \\
\text { (significance varies } \\
\text { with time) }\end{array}$ & $\begin{array}{c}\text { Ordinary least } \\
\text { squares method }\end{array}$ \\
\hline
\end{tabular}




\begin{tabular}{|c|c|c|c|c|c|c|}
\hline Gani (2011) & 84 countries & $1996-2005$ & $\begin{array}{l}\text { Real growth of } \\
\text { gross domestic } \\
\text { product (annual } \\
\text { percentage) } \\
\text { (World Bank, } \\
\text { 2007) }\end{array}$ & $\begin{array}{c}\text { Governance } \\
\text { indicators } \\
\text { (World Governance } \\
\text { indicators) }\end{array}$ & $\begin{array}{c}\text { Democracy - } \\
\text { negative and } \\
\text { significant } \\
\text { Political stability - } \\
\text { positive and significant } \\
\text { Government } \\
\text { effectiveness - } \\
\text { positive and significant } \\
\text { Regulatory quality - } \\
\text { negative and } \\
\text { insignificant } \\
\text { Rule of law - negative } \\
\text { and insignificant } \\
\text { Control of corruption - } \\
\text { negative and } \\
\text { significant }\end{array}$ & $\begin{array}{l}\text { Ordinary least } \\
\text { squares method }\end{array}$ \\
\hline $\begin{array}{c}\text { Seldadyo, } \\
\text { Nugroho and } \\
\text { Haan (2007) }\end{array}$ & 82 countries & $1984-2004$ & $\begin{array}{l}\text { Average GDP per } \\
\text { capita growth rates } \\
\text { (World Bank) }\end{array}$ & $\begin{array}{l}\text { Governance } \\
\text { (ICRG) }\end{array}$ & $\begin{array}{l}\text { Positive and } \\
\text { significant }\end{array}$ & $\begin{array}{l}\text { Parsimonious } \\
\text { regression }\end{array}$ \\
\hline $\begin{array}{l}\text { Commander and } \\
\text { Nikoloski (2010) }\end{array}$ & 159 countries & $1960-2009$ & $\begin{array}{c}\text { Per capita GDP } \\
\text { growth } \\
\text { (World Penn Table) } \\
\text { Real GDP growth } \\
\text { (World } \\
\text { Development } \\
\text { Indicators) }\end{array}$ & $\begin{array}{c}\text { Democracy } \\
\text { (Freedom House } \\
\text { and Polity IV) }\end{array}$ & $\begin{array}{l}\text { Positive and } \\
\text { insignificant }\end{array}$ & GMM \\
\hline $\begin{array}{l}\text { Law and } \\
\text { Habibullah } \\
(2006)\end{array}$ & $\begin{array}{l}8 \text { East Asian } \\
\text { countries }\end{array}$ & $1980-2001$ & $\begin{array}{l}\text { Real GDP per } \\
\text { capita } \\
\text { (World Bank) }\end{array}$ & $\begin{array}{l}\text { Institutional quality } \\
\text { (ICRG) }\end{array}$ & $\begin{array}{l}\text { Institutional quality, } \\
\text { Rule f aw, } \\
\text { Bureaucracy and } \\
\text { corruption - Positive } \\
\text { and significant } \\
\end{array}$ & FMOLS \\
\hline
\end{tabular}

\section{Overview of governance and growth meta-regression analysis}

\begin{tabular}{|c|c|c|c|c|c|c|}
\hline Field & $\begin{array}{c}\text { Search } \\
\text { engines used }\end{array}$ & Types of data included & Effect size & $\begin{array}{c}\text { Number of } \\
\text { studies } \\
\text { (Estimates) }\end{array}$ & Countries studied & Aims of study \\
\hline $\begin{array}{c}\text { Economic } \\
\text { governance and } \\
\text { economic growth }\end{array}$ & Various & English language & $\begin{array}{c}\text { Partial } \\
\text { correlation } \\
\text { unpublished }\end{array}$ & $\begin{array}{c}29\left(554^{*}\right) \\
\begin{array}{c}\text { South and East Asia \& } \\
\text { Pacific countries as } \\
\text { defined by world bank }+ \\
\text { South Korea }\end{array}\end{array}$ & $\begin{array}{c}\text { Parameter } \\
\text { estimate and } \\
\text { heterogeneity }\end{array}$ \\
\hline
\end{tabular}

"Total number of estimates (combining all measures of governance) 


\section{Effect of moderator variables}

\begin{tabular}{|c|c|c|c|c|c|c|c|c|c|c|c|c|}
\hline \multirow[t]{2}{*}{ Moderator variable } & \multicolumn{2}{|c|}{ Political Stability } & \multicolumn{2}{|c|}{$\begin{array}{l}\text { Government } \\
\text { Effectiveness }\end{array}$} & \multicolumn{2}{|c|}{ Regulation } & \multicolumn{2}{|c|}{ Law } & \multicolumn{2}{|c|}{ Corruption } & \multicolumn{2}{|c|}{ Aggregate Governance } \\
\hline & WLS & Cluster & WLS & Cluster & WLS & Cluster & WLS & Cluster & WLS & Cluster & WLS & Cluster \\
\hline \multicolumn{13}{|c|}{ Study related aspects } \\
\hline \multicolumn{13}{|c|}{ Reference category: if the estimate is taken from a model that has included education related variable } \\
\hline $\begin{array}{l}\text { If the estimate is } \\
\text { taken from a model } \\
\text { that has included } \\
\text { population variable }\end{array}$ & & & & & & & $\begin{array}{c}0.22 \\
(1.91)\end{array}$ & $\begin{array}{c}0.22 \\
(1.28)\end{array}$ & & & $\begin{array}{c}-0.25 \\
(-2.51)\end{array}$ & $\begin{array}{c}-0.25 \\
(-7.45)\end{array}$ \\
\hline $\begin{array}{c}\text { If the estimate is } \\
\text { taken from a model } \\
\text { that has included } \\
\text { domestic investment } \\
\text { variable }\end{array}$ & & & & & & & & & & & $\begin{array}{c}0.55 \\
(5.17)\end{array}$ & $\begin{array}{c}0.55 \\
(17.55)\end{array}$ \\
\hline \multicolumn{13}{|c|}{ Reference category: if the estimate has used growth data from World Bank } \\
\hline $\begin{array}{l}\text { If the estimate has } \\
\text { used growth data } \\
\text { from International } \\
\text { Monetary Fund } \\
\text { database }\end{array}$ & & & $\begin{array}{c}-1.64 \\
(-5.07)\end{array}$ & $\begin{array}{c}-1.64 \\
(-72.95)\end{array}$ & & & & & & & & \\
\hline \multicolumn{13}{|c|}{ Reference category: if the estimate has used governance data from World Bank } \\
\hline $\begin{array}{l}\text { If the estimate is } \\
\text { estimated using } \\
\text { governance data } \\
\text { from International } \\
\text { Country Risk Guide }\end{array}$ & & & & & & & & & & & $\begin{array}{c}-0.73 \\
(-4.81)\end{array}$ & $\begin{array}{c}-0.73 \\
(-7.46)\end{array}$ \\
\hline $\begin{array}{l}\text { If the estimate is } \\
\text { estimated using } \\
\text { governance data } \\
\text { from Polity database }\end{array}$ & $\begin{array}{c}-0.13 \\
(-4.51)\end{array}$ & $\begin{array}{c}-0.13 \\
(-10.07)\end{array}$ & & & & & & & & & & \\
\hline \multicolumn{13}{|c|}{ Reference category: if the estimate is taken from a model that has used non-yearly data on growth } \\
\hline $\begin{array}{l}\text { If the estimate is } \\
\text { taken from model } \\
\text { that has used yearly } \\
\text { data on growth }\end{array}$ & $\begin{array}{c}0.58 \\
(2.61)\end{array}$ & $\begin{array}{c}0.58 \\
(4.43)\end{array}$ & & & $\begin{array}{c}1.53 \\
(16.96)\end{array}$ & $\begin{array}{c}1.53 \\
(5216.23)\end{array}$ & $\begin{array}{c}0.45 \\
(3.67)\end{array}$ & $\begin{array}{c}0.45 \\
(2.01)\end{array}$ & $\begin{array}{c}-1.19 \\
(-38.63)\end{array}$ & $\begin{array}{c}-1.19 \\
(-310.19)\end{array}$ & & \\
\hline & & & & ence & : if the 1 & is estimate & ng other & iiques & & & & \\
\hline
\end{tabular}




\begin{tabular}{|c|c|c|c|c|c|c|c|c|c|c|c|c|}
\hline $\begin{array}{c}\text { If the estimate } \\
\text { belongs to a model } \\
\text { that is estimated } \\
\text { using panel data } \\
\text { techniques }\end{array}$ & $\begin{array}{c}0.71 \\
(1.73)\end{array}$ & $\begin{array}{c}0.71 \\
(2.91)\end{array}$ & & & & & $\begin{array}{c}-0.20 \\
(-2.75)\end{array}$ & $\begin{array}{c}-0.20 \\
(-2.93)\end{array}$ & & & & \\
\hline $\begin{array}{l}\text { If the estimate } \\
\text { belongs to a model } \\
\text { that is estimated } \\
\text { using instrumental } \\
\text { variable techniques }\end{array}$ & & & & & & & & & & & $\begin{array}{c}-0.23 \\
(-1.68)\end{array}$ & $\begin{array}{c}-0.23 \\
(-2.86)\end{array}$ \\
\hline \multicolumn{13}{|c|}{ Reference category: if the estimate is taken from a model in which observations are not reported } \\
\hline $\begin{array}{l}\text { If the estimate is } \\
\text { taken from a model } \\
\text { in which } \\
\text { observations are } \\
\text { reported }\end{array}$ & & & $\begin{array}{c}0.42 \\
(5.13)\end{array}$ & $\begin{array}{c}0.42 \\
(25.57)\end{array}$ & & & & & $\begin{array}{c}-1.51 \\
(-6.31)\end{array}$ & $\begin{array}{c}-1.51 \\
(-21.35)\end{array}$ & & \\
\hline \multicolumn{13}{|c|}{ Reference category: if the estimate is taken from a model that has used cross sectional data } \\
\hline $\begin{array}{c}\text { If the estimate is } \\
\text { taken from a model } \\
\text { that has used panel } \\
\text { data }\end{array}$ & & & & & $\begin{array}{c}-1.41 \\
(-18.45)\end{array}$ & $\begin{array}{c}-1.41 \\
(-4673.79)\end{array}$ & & & & & & \\
\hline \multicolumn{13}{|c|}{ Author related factors } \\
\hline \multicolumn{13}{|c|}{ Reference category: if the first author of the study is from other universities } \\
\hline $\begin{array}{l}\text { If the first author of } \\
\text { the study is from } \\
\text { European University }\end{array}$ & & & & & $\begin{array}{c}-0.58 \\
(-7.20)\end{array}$ & $\begin{array}{c}-0.58 \\
(-3055.74)\end{array}$ & $\begin{array}{c}-0.24 \\
(-22.97)\end{array}$ & $\begin{array}{c}-0.24 \\
(-5.53)\end{array}$ & & & & \\
\hline \multicolumn{13}{|c|}{ Real world factors } \\
\hline \multicolumn{13}{|c|}{ Reference category: if the estimate belongs to a model that has not included South Korea in the list of sample countries } \\
\hline $\begin{array}{l}\text { If the estimate } \\
\text { belongs to a model } \\
\text { that has included } \\
\text { South Korea in the } \\
\text { list of sample } \\
\text { countries }\end{array}$ & & & & & & & & & & & $\begin{array}{c}0.43 \\
(3.49)\end{array}$ & $\begin{array}{c}0.43 \\
(4.47)\end{array}$ \\
\hline No. of observations & 14 & 14 & 36 & 36 & 9 & 9 & 48 & 48 & 78 & 78 & 36 & 36 \\
\hline Adj R2 & 0.95 & 0.96 & 0.69 & 0.72 & 0.99 & 0.99 & 0.97 & 0.98 & 0.96 & 0.96 & 0.92 & 0.93 \\
\hline
\end{tabular}

Note: Only variables that have a significant effect are shown. Values in parenthesis show t-values. See appendix 4 for full descriptive statistics of moderator variables included in multiple meta-regression. 


\section{REFERENCES}

[1] ADAMS, S. \& MENGISTU, B. 2008. Privatization, Governance and Economic Development in Developing Countries. Journal of Developing Societies (Netherlands), 24, 415-438.

[2] AISEN, A. \& VEIGA, F.J. 2011. How does Political Instability Affect Economic Growth? IMF Working Paper. $\mathrm{WP} / 11 / 12$.

[3] ALONSO, J. A. 2010. Colonisation, Institutions and Development: New Evidence. Journal of Development Studies, 47, 7, 937 - 958.

[4] ANWAR, S. \& COORAY, A. 2012. Financial development, political rights, civil liberties and economic growth: Evidence from South Asia. Economic Modelling, 29, 974-981.

[5] ASSIOTIS, A. \& SYLWESTER, K. 2012. Do the Effects of Corruption upon Growth Differ Between democracies and Autocracies? University of Cyprus Working Papers in Economics.

[6] BUSSE, M. \& GROIZARD, J. L. 2008. Foreign Direct Investment, Regulations and Growth. The World Economy.

[7] BUTKIEWICZ, J. L. \& YANIKKAYA, H. 2004. Institutional quality and economic growth: maintenance of the rule of law or democratic institutions, or both? Economic modeling, 23, 648-661.

[8] BUTKIEWICZ, J. L. \& YANIKKAYA, H. 2011. Institutions and the impact of government spending on growth. Journal of Applied Economics, 14, 319-341.

[9] CAMPOS, N. F. \& KINOSHITA, Y. 2010. Structural Reforms, Financial Liberalization, and Foreign Direct Investment. IMF Staff Papers, 57, 326-365.

[10] CAMPOS, N. F. \& NUGENT, J. B. 1999. Development performance and the institutions of governance: Evidence from East Asia and Latin America. World Development, 27, 439-452.

[11] CENTRE FOR REVIEWS AND DISSEMINATION (CRD). 2009. Systematic reviews: CRD's guide for undertaking reviews in health care. York, UK: Publishing Services.

[12] COMMANDER, S. \& NIKOLOSKI, Z. 2010. Institutions and Economic Performance: What can be explained? European Bank for Reconstruction and Development Working Paper Number, 21.

[13] DAHLSTROM, T. \& JOHNSON, A. 2007. BUREAUCRATIC CORRUPTION, MNEs AND FDI. CESIS Electronic Working Paper Series, 82.

[14] DOUCOULIAGOS, H. IAMSIRARAOJ, S. \& ULUBASOGLU, M. A. 2010. Foreign Direct Investment and Economic Growth: A real relationship or wishful thinking? Deakin University Working Paper SWP 2010/14.

[15] DOUCOUliagos, H, \& PALDAM, M. 2008. Aid effectiveness on growth: a meta study. European Journal of Political Economy, 24, 1, 1-24.
[16] DouCOUliagos, H, \& PALDAM, M. 2009. The aid effectiveness literature: the sad results of 40 years of research. Journal of Economic Surveys, 23, 3, 433 - 461.

[17] DOUCOULIAGOS，H，\& ULUBAȘOĞLU， M. 2008, 'democracy and economic growth: a meta-analysis', American Journal of Political Science, 52, 1, 61-83.

[18] DRURY, A. C., KRIECKHAUS, J. \& LUSZTIG, M. 2006. Corruption, Democracy and Economic Growth. International Political Science Review, 27, 2, 121 - 136.

[19] EASTERLY, W. 1999. Life during Growth. Journal of Economic Growth, 4, 239 - 275.

[20] EKANAYAKE, E. M. \& CHATRNA, D. 2010. The Effect of Foreign Aid on Economic Growth in Developing Countries. Journal of International Business and Cultural Studies, 3, 2, 1 -13 .

[21] EPPI CENTRE. 2010. EPPI Centre Methods for Conducting Systematic Reviews. Evidence for Policy and Practice Information and Co-ordinating Centre, Institute of Education, University of London.

[22] EVANS, P. \& RAUCH, J. E. 1999. Bureaucracy and growth: a cross-national analysis of the effects of "weberian" state structures on economic growth. American Sociological Review, 64, 748-765.

[23] EVRENSEL, A. Y. 2010. Corruption, growth, and growth volatility. International Review of Economics \& Finance, 19, 501-514.

[24] FEENY, S. 2005. The Impact of Foreign Aid on Economic Growth in Papua New Guinea. The Journal of Development Studies, 41, 6, 1092 - 1117.

[25] FEENY, S. \& McGILliVRAY, M. 2010. Aid and Growth in Small Island Developing States. Journal of Development Studies, 46, 5, 897 - 917.

[26] FERNÁNDEZ, A. I., GONZÁLEZ, F. \& SUÁREZ, N. 2010. How institutions and regulation shape the influence of bank concentration on economic growth: International evidence. International Review of Law and Economics, 30, 28-36.

[27] GANI, A. 2011. Governance and Growth in Developing Countries. Journal of Economic Issues (M.E. Sharpe Inc.), 45, $19-40$.

[28] GLOBERMAN, S. \& SHAPIRO, D. 2002. Global foreign direct investment flows: The role of governance infrastructure. World Development, 30.

[29] GOLDSMITH, A. A. 1995. Democracy, Property Rights and Economic Growth. The Journal of Development Studies, 32, 2, $157-174$.

[30] HAGGARD, S. \& TIEDE, L. 2011. The rule of law and economic growth: where are we? World development, 39, 673-685.

[31] HUNTINGTIN, S. 1968. Political order in changing societies. New Haven. CT: Yale University Press.

[32] JALILIAN, H., KIRKPATRICK, C. \& PARKER, D. 2007. The Impact of Regulation on Economic Growth in Developing Countries: A Cross-Country Analysis. World Development, 35, 87-103. 
[33] KHAMFULA, Y. 2007. Foreign Direct Investment and Economic Growth in EP and IS Countries: The Role of Corruption. World Economy, 30, 1843-1855.

[34] KAUFMANN, D., KRAAY, A. \& ZOIDO-LOBATON, P. 1999. Aggregating Governance Indicators. World Bank Policy Research Department Working Paper No. 2195.

[35] KAUFMANN, D., KRAAY, A., \& ZOIDO-LOBATON, P. 1999. Governance Matters. Policy Research Working Paper, 2196.

[36] KAUFMANN, D., KRAAY, A., \& ZOIDO-LOBATON, P. 2007. Growth and Governance: A Reply. The Journal of Politics, 69, 2, 555 - 562.

[37] KLEIN, M. 2005. Capital Account Liberalization, Institutional Quality and Economic Growth: Theory and Evidence. NBER Working Paper, 11112.

[38] LAW, S. H. \& HABIBULLAH, M. S. 2006. Financial Development, Institutional Quality and Economic Performance in East Asian Economies. Review of Applied Economics, 2, 2, $201-216$.

[39] LEFF, N. 1964. Economic development through bureaucratic corruption. American Behavioural Scientist, 82, 337 - 41.

[40] LUI, F.T. 1985. An equilibrium queuing model of bribery. Journal of Political Economy, 93, 760 - 81.
[41] MAURO, P. 1995. Corruption and Growth. The Quarterly Journal of Economics, 110, 3, 681 - 712 .

[42] MO, P. H. 2001. Corruption and Economic Growth. Journal of Comparative Economics, 29, 66 - 79.

[43] NORTH, D. C. 1990. Institutions, Institutional Change and Economic Performance. Cambridge University Press.

[44] OLIVA, M.-A. \& RIVERA-BATIZ, L. A. 2002. Political Institutions, Capital Flows, and Developing Country Growth: An Empirical Investigation. Review of Development Economics, 6, 248.

[45] SELDADYO, H., NUGROHO, E. P. \& DE HAAN, J. 2007. Governance and Growth Revisited. Kyklos, 60, 279-290.

[46] STANLEY, T, DOUCOULIAGOS, C, \& JARRELL, S. 2008. Meta-regression analysis as the socio-economics of economics research, Journal of Socio-Economics, 37, 1, pp. 276-292.

[47] Stanley, T. D \& DOUCOUliagos, H. 2012. Meta-Regression Analysis in Economics and Business. Oxford Routledge.

[48] ZHANG, K. H. 2001. Does foreign direct investment promote economic growth? Evidence from East Asia and Latin America. Contemporary Economic Policy, 19. 